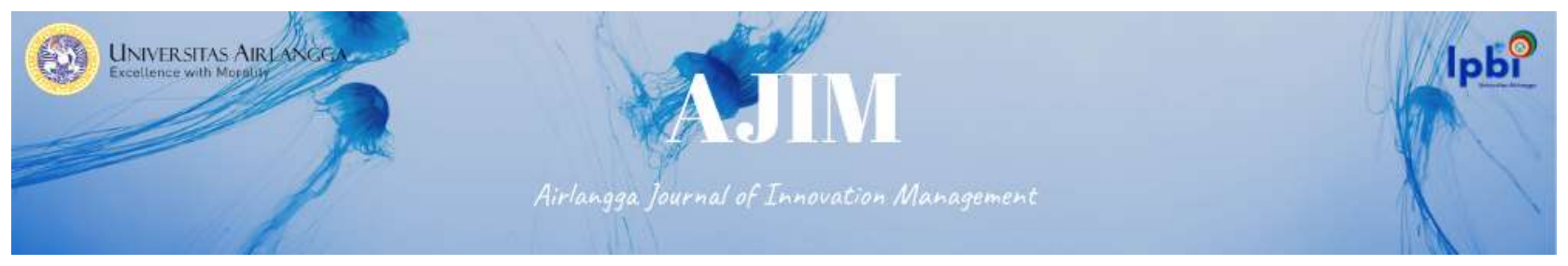

Vol.1, No.1, June 2020

e-ISSN: 2722-5062

DOI : 10.20473/ajim.v1i1.18950

\title{
INOVASI NILAI DALAM KERANGKA PERGERSERAN SAMUDERA BIRU (BLUE OCEAN SHIFT) PADA INDUSTRI KACA LEMBARAN DI INDONESIA
}

\author{
Rudy Subagio \\ Fakultas Ekonomi dan Bisnis, Universitas Airlangga, Surabaya, Indonesia \\ E-mail: rudy_subagio@gmail.com
}

\begin{abstract}
Competition in the flat glass market in Indonesia since 2015 has been increasingly severe because muchimported glass has entered Indonesia. The rapid rate of imported glass entering Indonesia is caused by the enactment of the free trade pact in southeast Asia and secondly because of the expansion of the Chinese glass industry that built new factories in the Southeast Asia region, especially in Malaysia. Most of the imported glass entering Indonesia is commodity glass with a lower price compared to local products, while the local industry has difficulties in competing for the price because the production cost is already high. This research aims to explore the basic concepts of strategies carried out by local flat glass companies in the domestic market competition based on the value innovation concept in the framework of "Blue Ocean Shift". The method is an exploratory case study draws on an in-depth field study conducted in a local flat glass company based in Indonesia. The results show that the Blue Ocean Strategy is more appropriate to be used in the face of competition in the flat glass market compared to the Porter generic strategy used by PT Alpha Glass today. Thus, this research is expected to provide insight into the implementation of the Blue Ocean Strategy in the glass industry comprehensively to assist Alpha Glass in determining future strategic directions.
\end{abstract}

Keywords: Value Innovation, Flat Glass Industry, Blue Ocean Shift

\begin{abstract}
ABSTRAK
Persaingan di pasar kaca lembaran di Indonesia sejak tahun 2015 semakin berat dengan masuknya kaca impor dari luar. Pesatnya laju impor kaca yang masuk ke Indonesia disebabkan oleh setidaknya dua faktor, pertama karena diberlakukannya pakta perdagangan bebas di Asia Tenggara dan kedua karena ekspansi pabrik kaca China yang membangun pabrik-pabrik baru di wilayah Asia Tenggara, khususnya di Malaysia. Sebagian besar kaca impor yang masuk ke Indonesia adalah kaca komoditas dengan harga lebih rendah dibandingkan dengan produk lokal, sementara industri kaca lembaran lokal mengalami kesulitan untuk menurunkan harga karena struktur biaya produksi sudah terlanjur tinggi. Penelitian ini bertujuan untuk mengeksplorasi konsep dasar strategi yang dilakukan oleh perusahaan kaca lembaran lokal dalam menghadapi persaingan di pasar kaca lembaran berdasarkan konsep inovasi nilai dalam kerangka "pergeseran samudra biru". Metode penelitian yang digunakan adalah studi kasus dengan melakukan studi lapangan secara mendalam pada perusahaan kaca lembaran lokal yang berbasis di Indonesia. Hasil penelitian menunjukkan bahwa Strategi Samudra Biru lebih tepat digunakan dalam menghadapi persaingan di pasar kaca lembaran saat ini dibandingkan dengan strategi generik Porter yang saat ini digunakan oleh PT Alpha Glass. Dengan demikian penelitian ini diharapkan dapat memberikan wawasan mengenai implementasi Strategi Samudra Biru pada industri kaca secara lengkap dan komprehensif bagi manajemen Alpha Glass dalam menentukan arah strategi kedepannya.
\end{abstract}




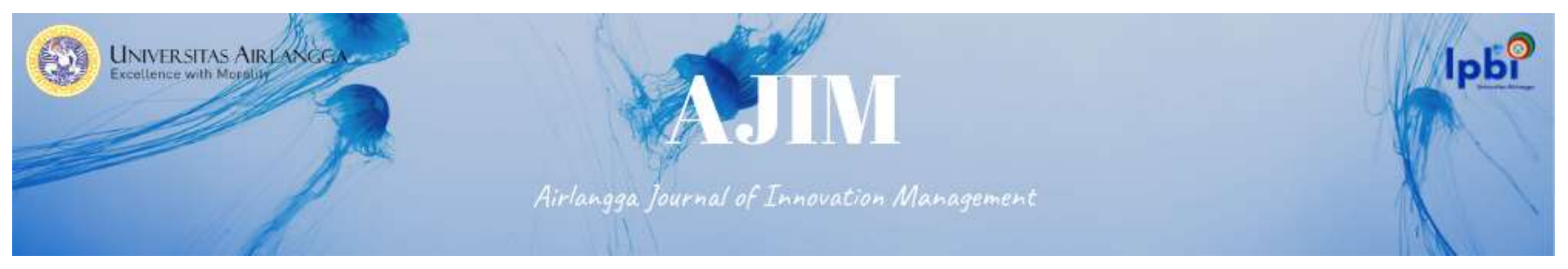

Kata kunci: Inovasi Nilai, Industri Kaca Lembaran, Pergeseran Samudra Biru

\section{PENDAHULUAN}

Industri kaca lembaran Indonesia mulai dibangun pada tahun 1971 dan berproduksi pada tahun 1973, awalnya untuk mengurangi ketergantungan pada kaca impor (Asahimas, n.d.). Seiring dengan laju pembangunan di Indonesia, industri kaca dalam negeri berkembang pesat dan pada puncaknya sekitar tahun 2000-an ada sekitar lima pemain (perusahaan) di industri kaca lembaran dalam negeri. Persaingan industri kaca lembaran dalam negeri yang semakin ketat menyebabkan para pemain industri kaca lembaran dalam negeri berguguran dan hanya menyisakan dua pemain yang masih bertahan sejak tahun 2017 (Dinnata, 2017).

Persaingan yang sangat ketat ini disebabkan masuknya kaca impor dari China dengan harga yang jauh lebih murah harganya dibandingkan pesaing-pesaingnya di industri kaca. China adalah produsen kaca lembaran terbesar yang memproduksi lebih dari 50 persen dari produksi global kaca lembaran dunia, China juga merupakan konsumen kaca terbesar di dunia, sekitar 50 persen dari permintaan dunia (NSG Group, 2010).

Pertumbuhan pabrik kaca lembaran di China mulai meningkat pesat pada sekitar tahun 2000-an. Dalam kurun waktu 10 tahun $(2001$ - 2011), jumlah float line di China telah meningkat hampir 3 kali lipat, dengan total produksi meningkat dari 12 juta ton menjadi 35 juta ton dalam kurun waktu 10 tahun (NSG Group, 2010). Dengan kapasitas total seluruh industri kaca lembaran di China yang sangat besar dan pertumbuhan industri China yang mulai melambat membuat mereka membidik pasar ekspor di kawasan Asia Tenggara.

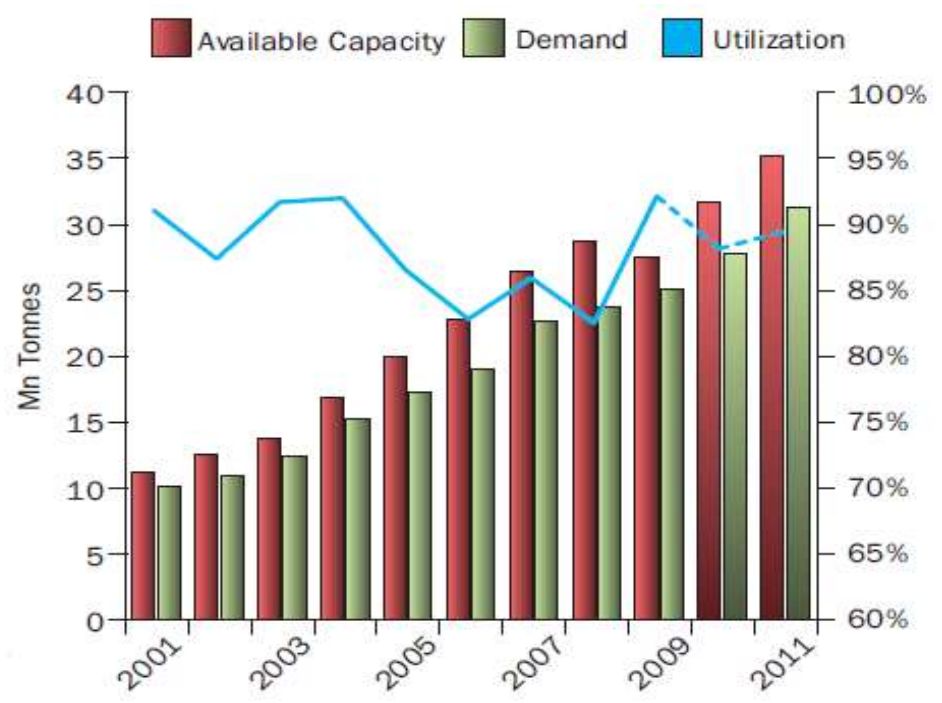

\section{Gambar 1. Total produksi kaca lembaran (float-line) di China 2001-2011 (Sumber : NSG Group, 2010)}

Sebagai dampak dari pertumbuhan industri kaca lembaran China yang pesat, sejak tahun 2012-2015 industri kaca lembaran China mulai masuk ke pasar kaca lembaran di kawasan Asia Tenggara, termasuk Indonesia. Pada awal-awal periode tersebut, kaca impor dari China langsung dikirim dari pabrik kaca lembaran yang berada di China, namun mulai tahun 2015 pabrik kaca lembaran China mulai melakukan ekspansi dengan membangun pabriknya di Malaysia. Pada tahun 2015-2016, Xinyi dan Kibing yang merupakan pemain besar di industri kaca lembaran di China telah membangun pabrik kaca lembaran di 


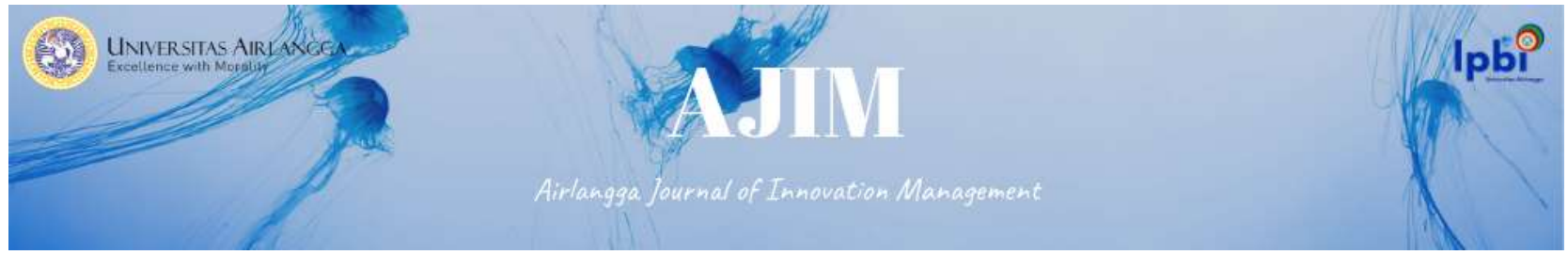

Malaysia (Morris, 2016; Kibing, 2016; Xinyi, 2016), dan mulai tahun 2017 mereka telah mengekspor produknya ke Indonesia. Secara total, jumlah kaca yang diekspor oleh pabrik kaca lembaran China yang berlokasi di China daratan maupun yang berada di Malaysia telah meningkat pesat dalam kurun waktu antara 2015 sampai dengan 2018. Selama periode tersebut, kaca impor yang masuk ke Indonesia meningkat hampir tujuh kali lipat, dari 18.6 kilo-ton pada tahun 2015 menjadi 128.2 kilo-ton pada tahun 2018 (UN-Comtrade, 2019). Sejak tahun 2017 pabrik kaca lembaran China yang berada di Malaysia mulai beroperasi penuh sehingga pengiriman kaca lembaran ke Indonesia yang semula dari pabrik yang ada di China mulai dikirim dari pabrik yang ada di Malaysia, selain karena jaraknya yang lebih dekat juga karena ada perjanjian perdagangan bebas (AFTA) di kawasan Asia Tenggara (Rini \& Ihsan, 2018).

Tabel. 1

Total volume kaca impor dari China dan Malaysia yang masuk ke Indonesia

\begin{tabular}{lcccc} 
& & \multicolumn{2}{c}{ Unit : kilo-ton } \\
\hline China & $\mathbf{2 0 1 5}$ & $\mathbf{2 0 1 6}$ & $\mathbf{2 0 1 7}$ & $\mathbf{2 0 1 8}$ \\
Malaysia & 17.5 & 33.2 & 74.7 & 27.4 \\
\hline Total & 1.1 & 1.1 & 30.4 & 100.8 \\
\hline
\end{tabular}

(Sumber : UN-Comtrade Database, 2019)

Menurut data dari Asosiasi Kaca Lembaran dan Pengaman [AKLP] Indonesia, kapasitas produksi kaca lembaran nasional saat ini adalah sekitar 1,3 juta ton per tahun, sedangkan permintaan untuk kaca lembaran di dalam negeri sekitar 800 kilo ton per tahun sehingga ada kelebihan sekitar 500 kilo ton untuk diekspor ke berbagai negara termasuk kawasan Asia Tenggara (AKLP, 2019),. Sejak produsen kaca China telah membangun pabrik baru di Malaysia, volume ekspor kaca lembaran Indonesia ke Malaysia selama periode 2015 - 2018 menurun secara signifikan, sehingga total volume ekspor kaca lembaran Indonesia secara global juga menurun (UN-Comtrade, 2019).

Tabel. 2

Total volume ekspor kaca lembaran Indonesia ke luar negeri

\begin{tabular}{lcccc}
\hline Destination & $\mathbf{2 0 1 5}$ & $\mathbf{2 0 1 6}$ & $\mathbf{2 0 1 7}$ & $\mathbf{2 0 1 8}$ \\
\hline All the World & 472.6 & 443.1 & 396.9 & 385.8 \\
Malaysia & 115.7 & 91.1 & 44.5 & 43.7 \\
\hline
\end{tabular}

(Sumber : UN-Comtrade Database, 2019)

Dengan kapasitas produksi kaca lembaran nasional yang sama, penurunan volume ekspor menyebabkan kelebihan produksi yang biasanya diekspor sekarang dijual di pasar domestik, sehingga penawaran dipasar domestik semakin meningkat jauh diatas permintaan karena masuknya kaca impor dan kelebihan produksi dari produsen dalam negeri yang biasanya dieskpor. Dengan demikian, persaingan di pasar kaca lembaran dalam negeri semakin lebih berat karena penawaran melebihi permintaan (AKLP, 2019).

Kondisi persaingan di pasar kaca lembaran yang sangat ketat seperti dijelaskan di atas dapat digambarkan sebagai persaingan Red Ocean atau "Samudra Merah" (Kim \& Mauborgne, 2005), dimana banyak pemain yang ikut berkompetisi pada ruang pasar yang sama, sehingga menjadikan persaingan menjadi sangat ketat dan berdarah-darah. Kondisi ini bila tidak diantisipasi akan mengancam kelangsungan hidup industri kaca lembaran di Indonesia di masa depan. Untuk menghadapi tantangan ini 


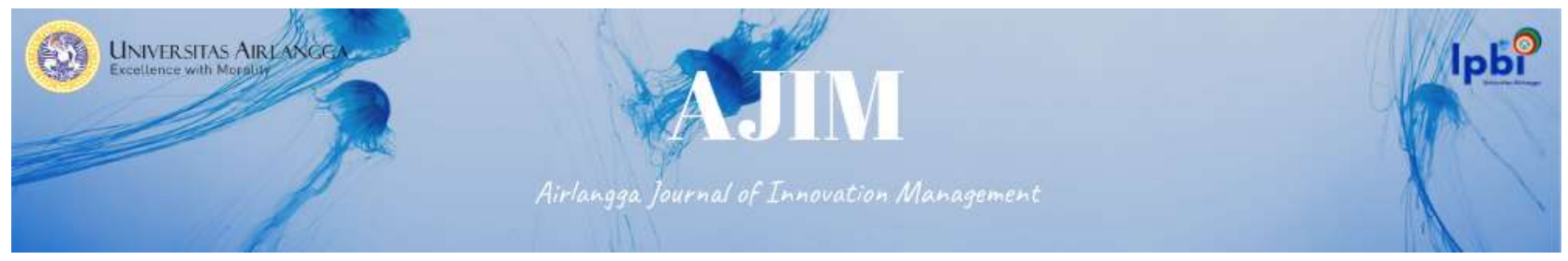

dibutuhkan strategi yang unggul yang didasarkan pada inovasi yang berkelanjutan.

Inovasi merupakan kunci sukses bagi sebuah organisasi, Ada beberapa pengertian mengenai inovasi, yang dirangkum menjadi 3 pandangan utama mengenai inovasi yaitu :

1. Innovation by Design (Gaynor, 2002)

2. The Art of Innovation (Kelly \& Littman, 2001)

3. Effective Innovation (Adair, 1996, 2009)

Menurut Gaynor (2002), inovasi adalah bidang ilmu manajemen memerlukan metodologi dalam mengatur dan mengelola sumber daya yang terbatas. Inovasi menuntut pendekatan secara sistematis dalam mengelola serta mengoptimalkan sumber daya sebuah organisasi. Menurut Kelly \& Littman (2001), inovasi adalah mengenai tindakan atau sebuah proses bukan tentang kesempurnaan atau hasil akhir. Mereka juga merekomendasikan pembuatan prototype, brainstorming, dan pengamatan sebagai dasar inovasi. Pandangan terakhir mengenai inovasi, menurut Adair (2009), inovasi adalah tentang bagaimana menghilangkan hambatan (mental block) pada diri seseorang dalam menghasilkan ide-ide baru dan cara kerja baru.

Penelitian ini akan berfokus pada perancangan dan pengembangan Blue Ocean Strategy (Strategi Samudra Biru) dalam kasus persaingan yang dihadapi oleh Alpha Glass. Sehingga pertanyaan utama dalam penelitian ini adalah :

Strategi bisnis apa yang dipandang lebih tepat bagi perusahaan kaca lembaran PT "Alpha Glass" untuk menghadapi persaingan melawan masuknya kaca impor yang harganya lebih murah?.

Dengan demikian tujuan dari penelitian ini adalah :

1. Mengeksplorasi strategi bisnis yang saat ini digunakan oleh PT Alpha Glass

2. Mengeksplorasi rancangan strategi bisnis apa yang lebih tepat bagi PT Alpha Glass dalam menghadapi persaingan dengan kaca impor dari China dan pesaing lokal di pasar kaca lembaran di Indonesia.

\section{TINJAUAN PUSTAKA}

Secara umum, ada beberapa jenis inovasi yaitu Inovasi Produk, Inovasi Bisnis Model dan Inovasi Pemasaran (Varadarajan, 2018). Dari semua jenis inovasi tersebut, konsep dasarnya adalah penciptaan nilai untuk memenuhi kebutuhan spesifik konsumen baik yang dapat diungkapkan maupun yang tidak. Bidang inovasi yang saat ini berkembang pesat dan didasarkan pada konsep penciptaan nilai adalah Inovasi Nilai, menurut Leavy (2018) setidaknya ada tiga variasi utama pada tema "inovasi nilai" hingga saat ini yaitu:

1. Blue Ocean Strategy (Kim \& Mauborgne, 2005)

2. Disruption Innovation (Christensen \& Raynor, 2003)

3. Co-creation Value (Prahalad \& Ramaswamy, 2004)

Ketiga varian inovasi nilai diatas mempunyai persamaan yaitu bagaimana cara menciptakan dan menangkap permintaan baru dengan berfokus pada pelanggan dan merubah dari non-pelanggan menjadi pelanggan melalui suatu lompatan nilai. Namun ketiganya juga mempunyai perbedaan dalam menyoroti jenis peluang ruang pasar baru, yaitu :

Strategi Samudra Biru cenderung berfokus pada inovasi nilai yang mengungkap permintaan / pasar yang sama sekali baru dengan mendefinisikan kembali kategori nilai yang diinginkan pelanggan, seperti Cirque de Soleil - hiburan yang menggabungkan sirkus dan teater (Kim \& Mauborgne, 2005).

Disruption Innovation cenderung berkonsentrasi pada penciptaan permintaan baru yang memperluas pasar yang dilayani saat ini, seperti Southwest dan Ryanair dalam bisnis perjalanan udara berbiaya rendah (Christensen \& Raynor,2003; Christensen et al., 2016).

Co-creation Value atau "inovasi pengalaman" ditujukan untuk menciptakan permintaan baru dengan mentransformasikan pengalaman pengguna, menawarkan "personalisasi yang dapat diskalakan" melalui penggunaan teknologi terhubung pintar yang ada di mana-mana untuk mengubah produk tradisional menjadi platform interaktif, informasi, keterlibatan, seperti yang dilakukan Nike dengan "Nike smart wearables" dan LEGO dengan mainan robotnya (Prahalad \& Ramaswamy, 2004). 


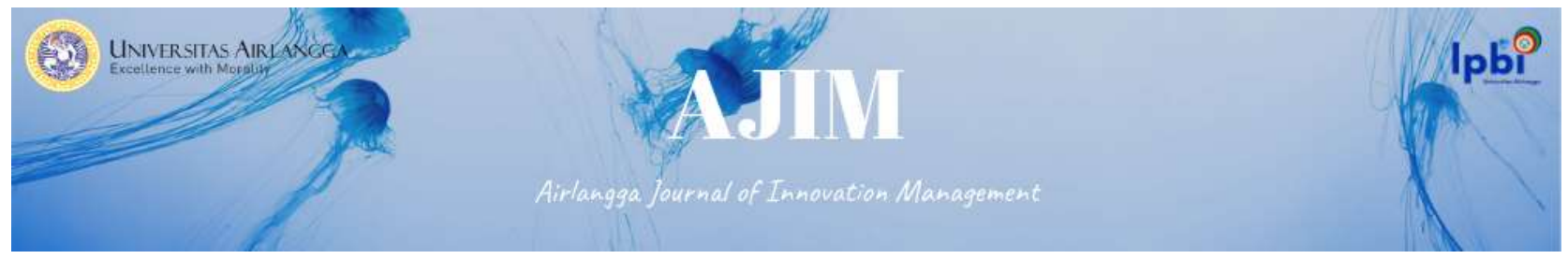

\section{Konsep Dasar Blue Ocen Shift (Pergeseran Samudra Biru)}

Strategi Samudra Biru pertama kali dikenalkan dalam buku Blue Ocean Strategy (2005), oleh Profesor Kim dan Mauborgne, yang dibangun diatas konsep inovasi nilai. Strategi ini kemdian diperbaharui dalam buku mereka yang baru, Blue Ocean Shift atau Pergeseran Samudra Biru, dalam buku yang terbaru ini Kim dan Mauborgne lebih menekankan bagaimana melakukan langkah-langkah pergeseran Samudra Biru yang sistematis dan berdasarkan pengalaman organisasi atau perusahaan yang telah sukses menerapkannya.

Alat analisa utama yang digunakan untuk menciptakan Samudra Biru, yaitu:

1) Strategi Kanvas dan Kurva Nilai

2) Kerangka Kerja Empat Tindakan dan Matrik ERRC

3) Enam Jalur untuk merekonstruksi Batas Pasar

4) Peta "Pioneer-Migrator-Settler"

5) Tiga Tingkat Nonkonsumen

6) Peta Utilitas-Pembeli

7) Tiga Karakteristik Strategi Blue Ocean yang Baik

Konsep dasar implementasi Pergeseran Samudra Biru dapat dirangkum dalam tiga komponen utama berikut ini (Kim \& Mauborgne, 2017).

1. Mengadopsi perspektif Samudra Biru. Terjadinya perubahan besar dalam pola pikir dari "samudra merah" ke pemikiran strategis "samudra biru", perlu kehati-hatian untuk menghindari "perangkap" kognitif samudra merah yang paling umum.

2. Mengoptimalkan alat analisis utama untuk menciptakan pasar baru. Pada dasarnya alat dipergunakan sama seperti dalam Blue Ocean Strategy dengan panduan lebih lanjut tentang bagaimana menerapkannya sebagai bagian tidak terpisahkan dari "perjalanan transformasi" Samudra Biru.

3. Memiliki "proses humanistik."Pergeseran Samudra Biru yang sukses juga ditandai oleh suatu proses yang secara inheren "mengakui orang, mengakui ketakutan mereka, rasa tidak aman mereka, kebutuhan mereka untuk diperlakukan dengan bermartabat, keinginan mereka untuk peduli.

Ketiga komponen penting di atas dijabarkan ke dalam proses lima langkah sistematis untuk membantu organisasi mengembangkan dan melaksanakan strategi penciptaan pasar baru yang sukses (Kim \& Mauborgne, 2017). Lima langkah tersebut adalah:

1. Memulai.

2. Memahami di mana perusahaan berada sekarang.

3. Membayangkan di mana perusahaan bisa berada.

4. Menemukan cara menuju ke sana.

5. Melakukan gerakan.

\section{METODE}

Penelitian ini menggunakan pendekatan kualitatif dan metode penelitian yang digunakan adalah studi kasus eksplorasi (exploratory case study). Penelitian ini dilakukan berdasarkan studi kasus pada satu perusahaan, dengan tujuan untuk memetakan kondisi persaingan industri kaca dalam negeri saat ini dan merancang pilihan strategi yang paling tepat untuk menjawab tantangan tersebut. Studi kasus dilaksanakan pada salah satu industri kaca lembaran terbesar dan pertama di Indonesia, yang dalam penelitian ini akan disebut dengan nama samaran PT "Alpha Glass", untuk menjaga kerahasiaannya. Perusahaan ini dipilih karena merupakan pelopor industri kaca lembaran di Indonesia dan juga perusahaan dengan kapasitas paling besar dan menguasai pangsa pasar kaca lembaran terbesar di seluruh Indonesia. Penelitian dilakukan dalam kurun waktu 2018 - 2019, yang merupakan masa paling sulit bagi industri kaca lembaran dalam negeri dalam menghadapi persaingan dengan produk kaca impor dari China, karena sejak 2016, industri kaca lembaran China mulai berekspansi secara besar-besaran dengan mendirikan pabrik kaca lembaran di Malaysia. 


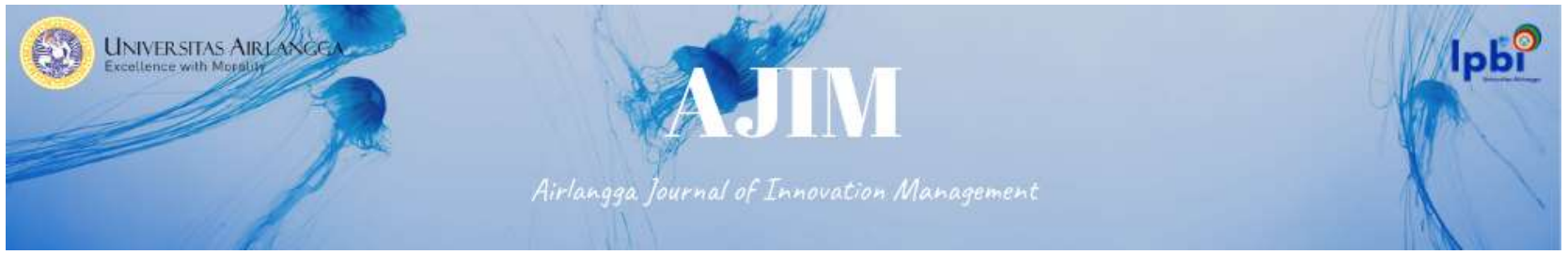

Data yang digunakan dalam penelitian ini didapatkan melalui wawancara terhadap tim manajemen puncak organisasi yang terdiri dari General Manager, Factory Manager, Production Manager dan Sales \& Marketing Manager, mereka dipilih karena terlibat langsung dalam penyusunan dan pelaksanaan strategi perusahaan. Metode wawancara yang dipakai adalah wawancara semi terstruktur (semi structured interviews) dimana daftar pertanyaan awal sudah disipakan namun demikian dalam perjalanannya dapat disesuiakan berdasarkan tanggapan saat itu. Hasil wawancara didokumentasikan dalam bentuk transkrip wawancara dan untuk mempertahankan anonimitas orang yang diwawancarai, mereka disebut sebagai Manajer Senior 1, Manajer Senior 2 dan seterusnya. Data sekunder dikumpulkan dari dokumen perusahaan termasuk baik dokumen strategi perusahaan atau business policy maupun dokumen umum perusahaan. Data pelengkap didapatkan dari laporan tahunan (annual report) industri kaca dalam negeri maupun luar negeri yang telah go-public, media massa baik cetak maupun elektronik, internet dan data arsip atau file database dari Badan Pusat Statistik (BPS) dan Asosiasi Kaca Lembaran dan Pengaman (AKLP) Indonesia, serta data ekspor-impor yang dikeluarkan oleh UN-Comtrade.

Wawancara yang dilakukan terhadap tim manajemen Alpha Glass bertujuan untuk mengeksplorasi konsep dasar strategi yang digunakan Alpha Glass saat ini dalam menghadapi persaingan di pasar kaca lembaran domestik. Strategi yang digunakan saat ini dianalisis dan dibandingkan dengan strategi Samudra Biru untuk mengetahui mengapa manajemen menggunakan strategi saat ini dan bukan strategi Samudra Biru. Untuk memastikan apakah Strategi Samudra Biru dapat digunakan dalam kasus persaingan yang dihadapi oleh Alpha Glass maka perlu disusun kerangka kerja strategi berdasarkan prinsip-prinsip pergeseran Samudra Biru. Penyusunan kerangka kerja strategi pergeseran Samudra Biru ini bertujuan untuk memberikan masukan serta wawasan kepada manajemen Alpha Glass mengenai aspek-aspek yang perlu diperhatikan dalam penerapan strategi inovasi nilai dalam kerangka pergeseran Samudra Biru

\section{HASIL DAN ANALISIS}

Kondisi persaingan yang dihadapi Alpha Glass saat ini dan peta persaingan dalam industri kaca lembaran di dalam negeri yang digambarkan dari hasil wawancara dengan manajemen Alpha Glass sebagai berikut :

Kondisi persaingan kaca lembaran di dalam negeri saat ini sangat berat, bukan saja karena produk impor dari China namun produsen dari China saat ini sedang membangun pabrik di Indonesia. Selain itu persaingan antar produsen kaca lembaran dalam negeri saat ini semakin ketat karena pabrik kaca lembaran dalam negeri tidak bisa menjual kaca ke kawasan Asia Tenggara karena kalah bersaing dengan produsen kaca lembaran China sehingga mereka lebih fokus untuk bersaing di dalam negeri (Senior Manager - 1)

Saat ini kondisi persaingan kaca lembaran dalam masa cukup berat, karena seperti kita ketahui bersama lahirnya kerjasama pakta perdagangan dimana Indonesia termasuk dalam pakta ekonomi asia tenggara, praktis para produsen dari china akan mencoba masuk dengan low price atau zero tariff dengan membangun pabriknya di kawasan Asia Tenggara khususnya di Malaysia, mereka adalah Kibing dan Xinyi. (Senior Manager - 3)

Dari penjelasan diatas kondisi persaingan diindustri kaca lembaran yang sangat ketat disebabkan oleh tiga hal yaitu, pertama masuknya kaca impor dari pabrik kaca lembaran China yang membangun pabriknya di Malaysia dengan harga yang sangat rendah. Kedua dikarenakan surplus produksi dalam negeri yang disebabkan para pemain industri kaca lembaran lokal saat ini tidak bisa menjual produknya ke kawasan Asia Tenggara sehingga mereka lebih fokus untuk menggarap pasar domestik, selain itu pabrik kaca lembaran China juga mulai membangun pabriknya di Indonesia yang akan mulai beroperasi sekitar tahun 2021. Ketiga karena penerapan kesepakatan perdagangan bebas kawasan Asia Tenggara.

Kondisi dan peta persaingan industri kaca lembaran dalam negeri yang sedang dihadapi oleh Alpha Glass seperti dipaparkan diatas menurut Kim \& Mauborgne (2005:45), kondisi tersebut dapat dikategorikan sebagai Samudra Merah. Kondisi tersebut mengharuskan Alpha Glass untuk segera keluar 


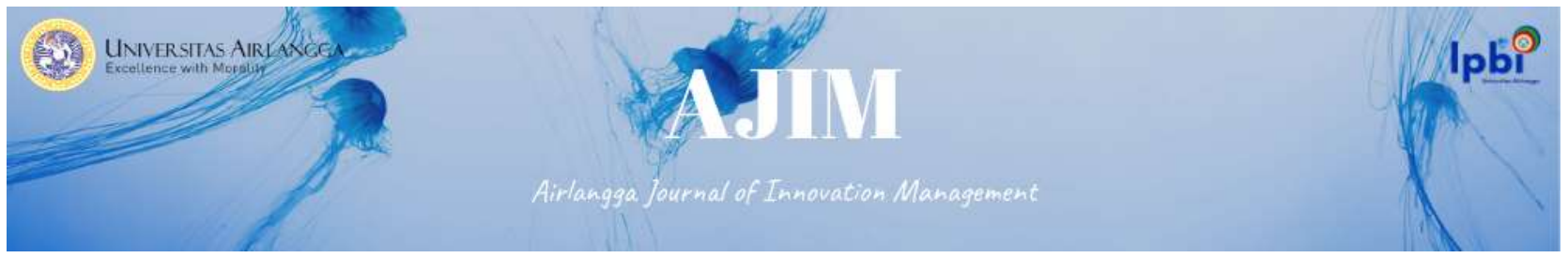

dari persaingan Samudra Merah dan melakukan Pergeseran Samudra Biru. Namun saat ini Alpha Glass belum menerapkan Strategi Samudra Biru, mereka mempunyai strateginya sendiri seperti yang dijelaskan oleh manajer senior berikut ini

Strategi yang paling tepat untuk saat ini adalah fokus menciptakan produk dan servis yang menarik bagi konsumen dan melakukan pekerjaan dengan sangat effisiensi. Hal yang dilakukan oleh Alpha Glass untuk menciptakan keunggulan (deferensiasi) produk dan layanan, contohnya melakukan peluncuran jenis produk / kaca baru dan menjamin On-time delivery, effisiensi dilakukan untuk menurunkan biaya... (Senior Manager - 1)

Salah satu strategi untuk menghadapi hal ini tentunya kita harus bergeser dari bisnis kaca komoditas ke kaca yang memiliki nilai lebih (Value Added Product) dan pada saat yang sama kita harus tetap mempertahankan posisi kita di pasar kaca komoditas dengan mengurangi biaya agar mampu bersaing dengan kompetitor. (Senior Manager - 3)

Dari penjelasan diatas, dapat disimpulkan bahwa strategi yang diterapkan oleh Alpha Glass saat ini adalah bergeser dari persaingan commodity glass menuju ke persaingan produk yang punya nilai lebih (Value Added Product). Persaingan pada produk commodity glass saat ini sudah mengarah pada perang harga akibat penawaran yang lebih besar dari permintaan pasar sehingga Alpha Glass memutuskan untuk fokus ke produk yang mempunyai nilai lebih atau Value Added Product.

Strategi yang digunakan Alpha Glass bukan Strategi Samudra Biru, manajemen Alpha Glass belum menerapkan Strategi Samudra Biru karena berbagai pertimbangan, salah satu diantaranya karena sampai saat ini belum kajian penerapan Strategi Samudra Biru di industri kaca lembaran, dan karena setiap strategi mengandung resiko maka kajian yang detail dan komprehensif perlu dilakukan sebelum mengambil keputusan. Oleh karena itu penelitian ini bertujuan untuk merancang langkah-langkah pergeseran Samudra Biru berdasarkan studi kasus yang terjadi di Alpha Glass.

\section{Lima Langkah Pergeseran Strategi Samudra Biru}

1. Langkah pertama : Memulai

Langkah pertama adalah memahami posisi portofolio perusahaan saat ini seperti yang digambarkan pada Peta "Penetap-Pejalan-Perintis", posisi portofolio Alpha Glass saat ini masih tergantung dari produk commodity glass yang dapat dikategorikan sebagai "penetap" atau "peniru nilai", dimana persaingan dalam katergori ini sangat ketat karena semua produsen dapat membuat produk tersebut sehingga cenderung mengarah ke perang harga.

Posisi portofolio Alpha Glass saat ini, secara umum digambarkan oleh salah satu manajer senior sebagai berikut.

Saat ini komposisi portofolio untuk produk kaca lembaran (flat glass) $45 \%$ VAP dan 55\% commodity glass namun pelan-pelan ini akan terus bergeser karena Alpha-Glass akan fokus ke $V A P$ sebagai main product sedangkan commodity glass hanya sebagai produk sampingan atau excess product, sehingga kedepannya komposisi portofolio akan menjadi VAP $70 \%$ dan $30 \%$ commodity glass sebagai target sampai 2025. (Senior Manager - 2)

Dari paparan diatas komposisi portofolio Alpha Glass saat ini didominasi oleh produk kaca biasa atau commodity glass yang menyumbang penjualan terbesar sampai saat ini. Namun demikian manajemen Alpha Glass sudah mulai mengantisipasi kondisi saat ini dengan mulai menyiapkan produkproduk yang akan menjadi andalan perusahaan di masa yang akan datang. Komposisi portofolio saat ini terdiri dari kaca biasa (non VAP) sekitar 55\% dan kaca dengan nilai tambah (VAP) sekitar $45 \%$ dan untuk 5 tahun kedepan komposisi ini akan berubah secara drastis menjadi 70\% kaca VAP dan 30\% nonVAP. Sehingga di masa depan kaca non-VAP hanya sebagai excess product atau produk sampingan dan kaca VAP akan menjadi main product atau produk utama. 


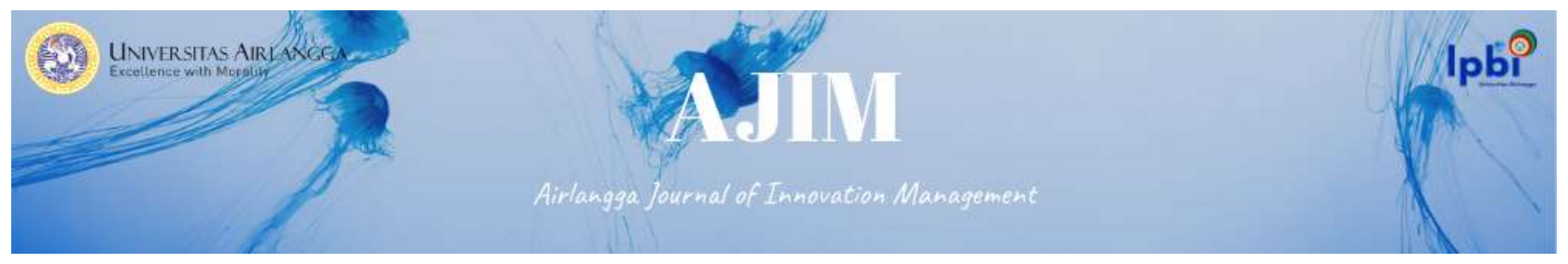

Berikut gambaran secara detail pergeseran portofolio perusahaan saat ini dan di masa depan berdasarkan jenis produk (Kind of Glass) dan kategorinya.

Tabel. 3

Komposisi portofolio Alpha Glass saat ini

\begin{tabular}{clccc}
\hline Product Category & Kind of Glass & Code & Sales Revenue & \% \\
\hline Commodity & Clear Glass & FL & $19 \%$ & $55 \%$ \\
Glass & Dark Grey & DG & $23 \%$ & \\
& Tinted+others & Tint. & $13 \%$ & \\
Value Added & Automotive & Auto & $17 \%$ & $45 \%$ \\
Product & Stopsol & SS & $11 \%$ & \\
& Sunergy & SN & $9 \%$ & \\
& Planible-G & PN & $0 \%$ & \\
& Mirror & Mi & $5 \%$ & \\
& Lacobel & LC & $1 \%$ & \\
& T-Sunlux & T-SLX & $2 \%$ & \\
& & & & \\
\hline
\end{tabular}

\section{(Sumber : Data diolah oleh penulis)}

Berdasarkan data di atas dapat digambarkan peta "penetap-pejalan-perintis" masa kini dan masa depan yang menggambarkan kondisi portofolio saat ini dan di masa depan.

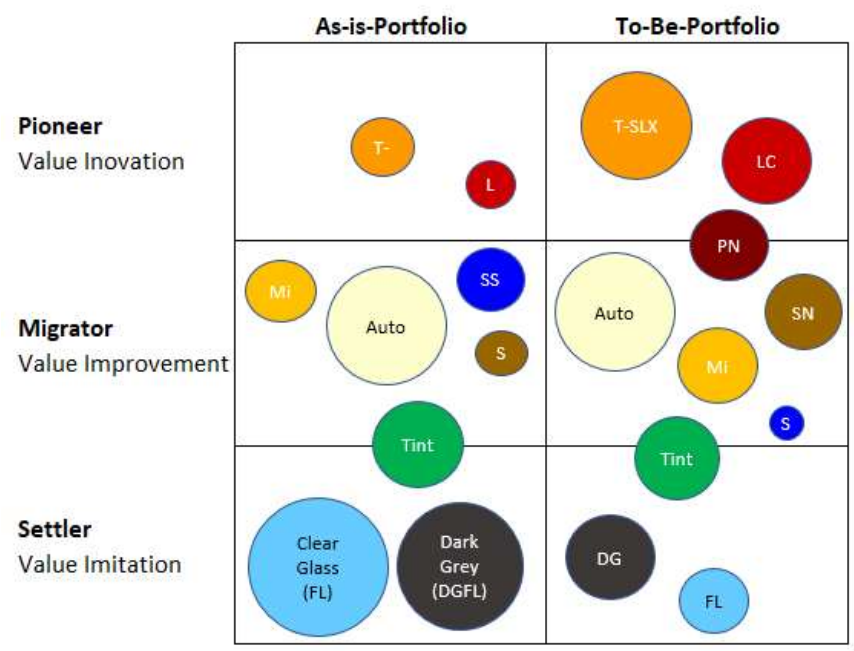

Gambar 2. Peta "Perintis - Pejalan - Penetap"

(Sumber : Data diolah oleh penulis)

Untuk melaksanakan langkah-langkah pergeseran Samudra Biru ini, sebaiknya Alpha Glass membentuk Tim Samudra Biru yang beranggotakan para manajer lintas departemen, dan setiap department diwakili oleh satu orang yang paling memahami kondisi perusahaan secara keseluruhan, termasuk kondisi persaingan yang dihadapai Alpha Glass dan kondisi internal departemennya. Tim ini bertanggung jawab langsung kepada General Manager dan semua kegiatan dievaluasi secara periodik dan 


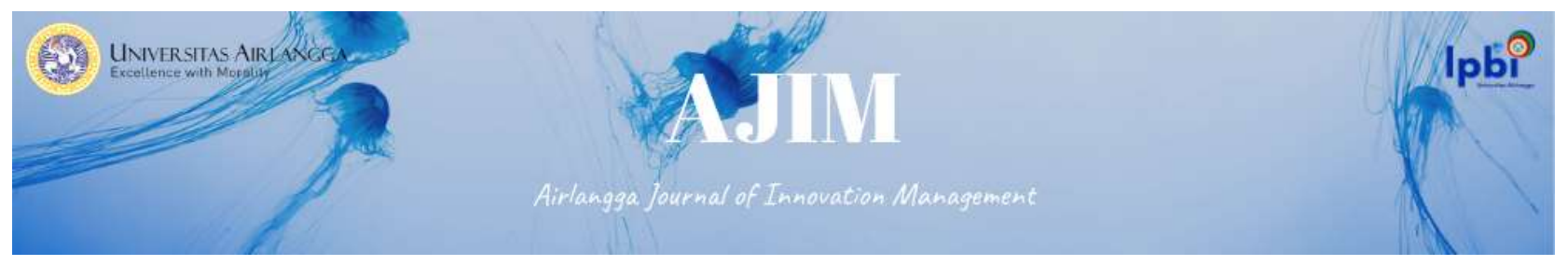

dilaporkan kepada General Manager.

2. Langkah kedua : Memahami posisi perusahaan saat ini

Posisi Alpha Glass di dalam peta persaingan industri kaca lembaran saat ini dapat digambarkan sebagai berikut:

Saat ini Alpha-glass merupakan market leader baik dalam pasar kaca lembaran (Flat Glass) maupun pada pasar kaca otomotif (Automotive Glass), dan saat ini masih menjadi pemain utama di industri kaca lembaran di Indonesia. (Senior Manager - 2)

Sebagai market leader di Indonesia, Alpha Glass saat ini menguasai sekitar 70\% pangsa pasar kaca Dark Grey, jauh diatas pesaing terdekat. Namun untuk kaca polos biasa pangsa pasarnya semakin menurun karena masuknya kaca impor dari China yang harganya lebih murah dan pesaing lokal yang harganya lebih rendah sekitar 3-5\%. (Senior Manager-3)

Berdasarkan paparan diatas dapat disimpulkan bahwa posisi Alpha Glass masih dominan sebagai market leader pasar kaca lembaran di dalam negeri. Namun demikian kedepannya kondisi persaingan semakin berat karena pesaing utama baik lokal maupun kaca impor makin agresif masuk ke pasar dengan menawarkan harga yang lebih rendah. Saat ini harga penawaran Alpha Glass masih lebih tinggi dari para pesaing namun dilain pihak biaya produksi sudah tinggi sehingga harga tidak bisa turun lagi untuk menyamai harga pesaing.

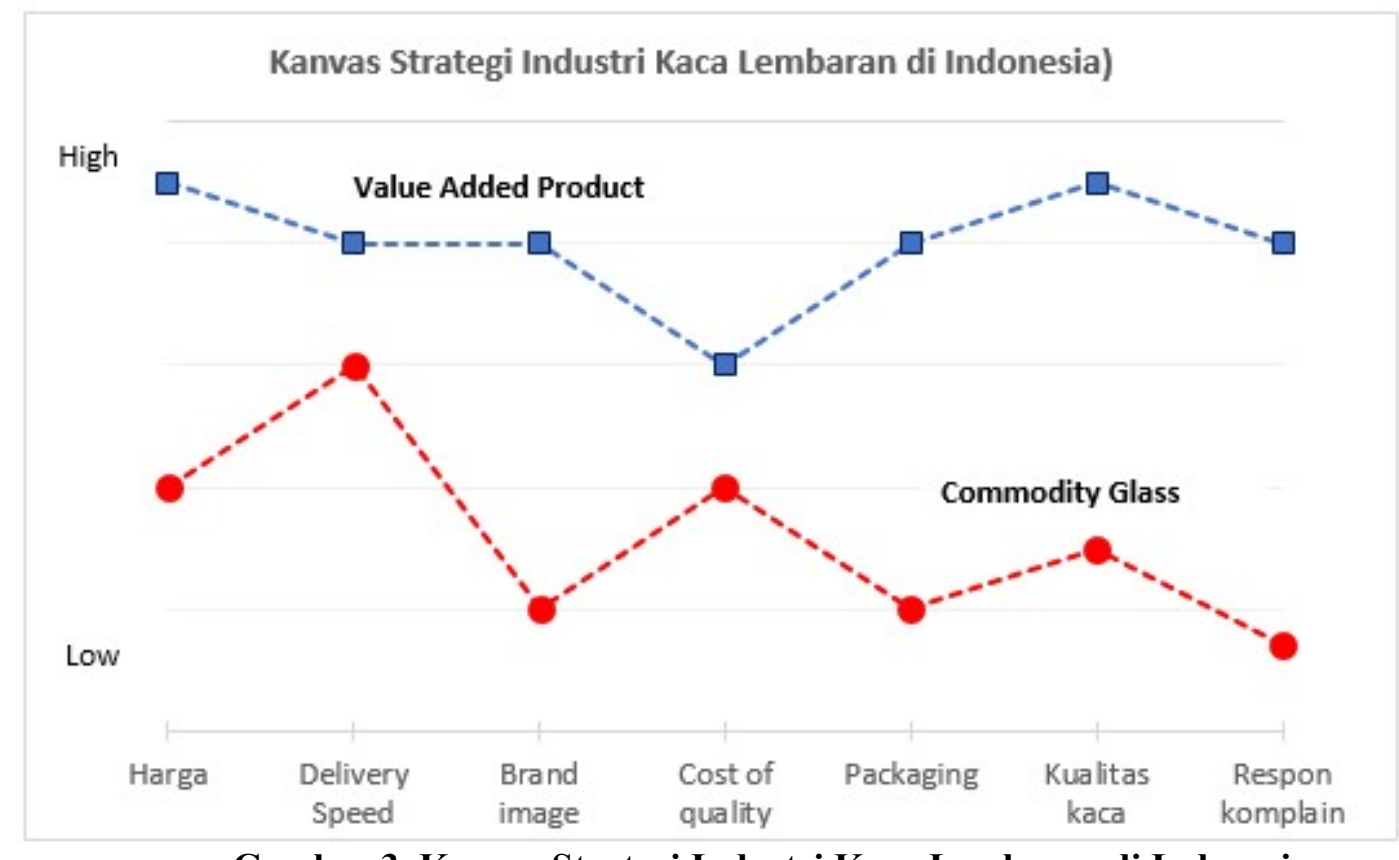

Gambar 3. Kanvas Strategi Industri Kaca Lembaran di Indonesia (Sumber : diolah dari data internal perusahaan)

Faktor-faktor yang diperebutkan dalam industri kaca lembaran dalam negeri yang digambarkan pada kanvas strategi adalah sebagai berikut:

1. Harga: harga kaca komoditas sangat rendah dibandingkan dengan kaca yang mempunyai nilai lebih atau Value Added Product (VAP), namun di masa depan sebagian VAP akan segera menjadi produk komoditas.

2. Pengiriman Tepat Waktu : merupakan faktor yang sangat penting bagi pelanggan karena sebagian besar kacas harus diproses sebelum dipasang di gedung sesuai dengan tenggat waktu proyek.

3. Brand Image: hal ini terkait dengan reputasi Alpha Glass dalam menyediakan produk berkualitas 


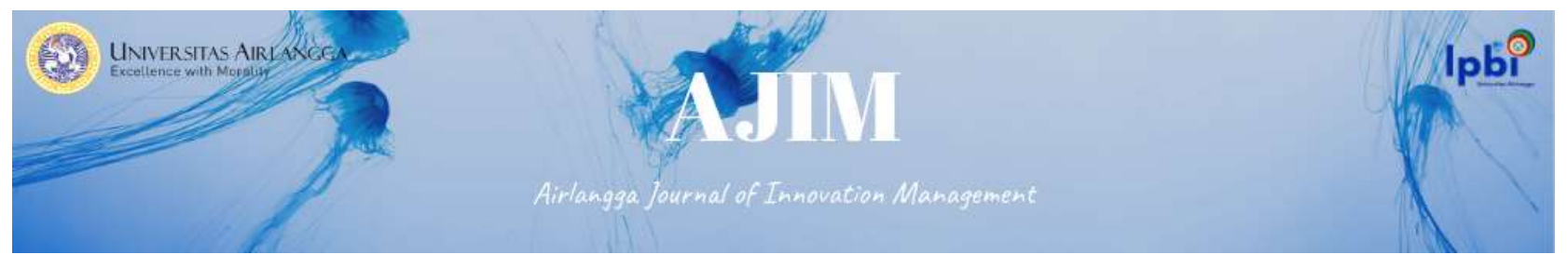

tinggi secara konsisten dalam jangka panjang dan respons yang cepat dalam menanggapi keluhan pelanggan.

4. Cost of Quality : terdiri dari biaya untuk mencegah produk cacat / ditolak / No-Good di internal perusahaan dan juga biaya yang dikeluarkan untuk menangani klaim dan keluhan dari pelanggan.

5. Packaging: kemasan memiliki fungsi sebagai pengaman untuk melindungi kaca di dalamnya dan pekerja yang menangani kaca tersebut, selain itu juga mengekspresikan tampilan produk.

6. Kualitas Kaca: secara visual ditentukan oleh homogenitas dan bebas dari gelembung udara atau material mikro yang tidak lebur dan transmisi visual sangat penting selama penggunaan, untuk kaca float berkualitas tinggi standarnya lebih ketat.

7. Layanan Purna Jual: respon yang cepat terhadap keluhan dari pelanggan dan proses kompensasi klaim yang cepat dan sederhana prosesnya.

3. Langkah ketiga : Menggambarkan posisi perusahaan yang bisa dicapai

Untuk menggambarkan posisi Alpha Glass dalam industri kaca di masa depan, yang pertama adalah mengungkapkan "titik menyakitkan tersembunyi" (hidden pain point) yang membatasi pertumbuhan Alpha Glass saat ini dan yang kedua adalah menemukan Samudra non-konsumen.

Titik menyakitkan tersembunyi (hidden pain point) dapat terungkap dari "peta utilitas pembeli". Gambar 4. adalah Peta utilitas pembeli Alpha Glass.

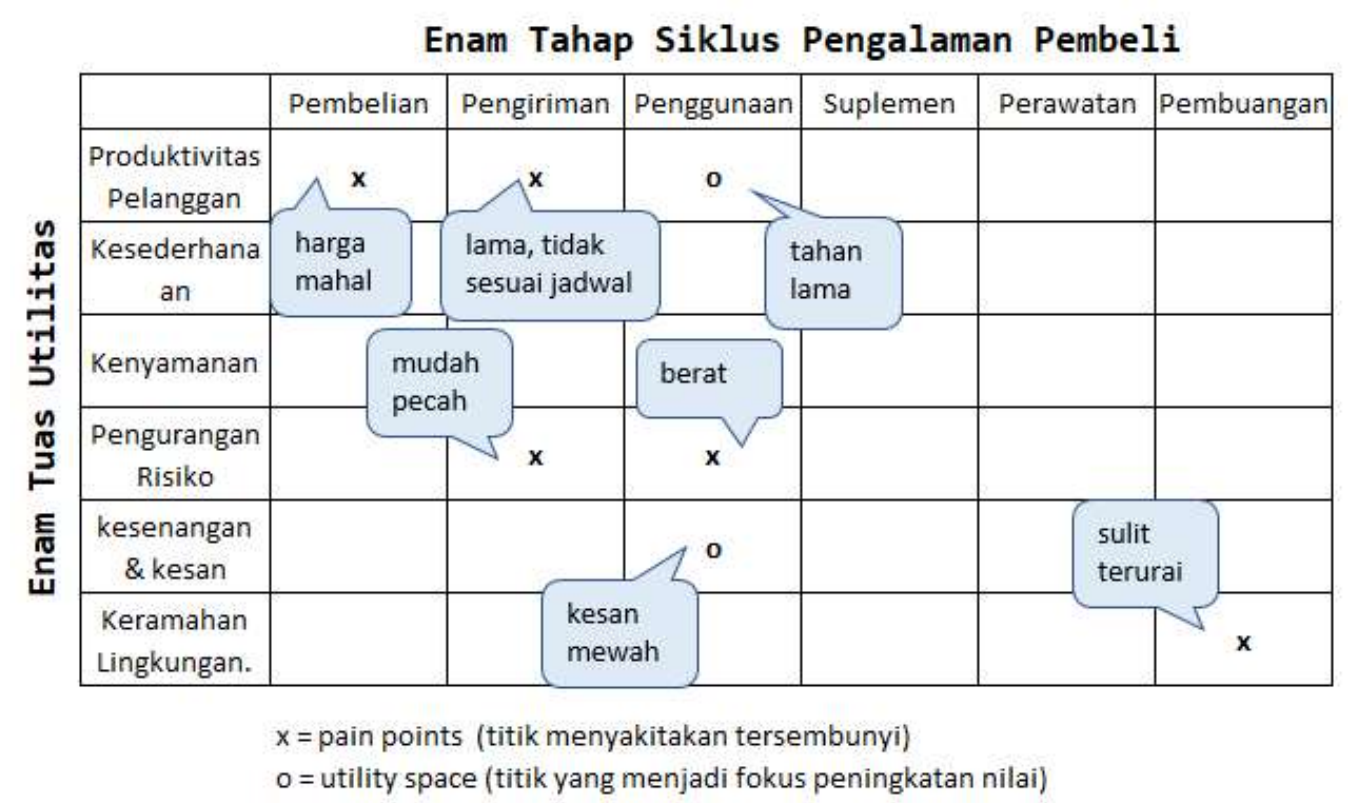

Gambar 4. Peta Utilitas Pembeli Alpha Glass
(Sumber : data diolah oleh penulis)

Hal-hal yang menjadi penghalang atau menyebabkan kesulitan bagi konsumen dalam setiap proses penggunaan atau "pain point" di industri kaca lembaran seperti harga yang mahal, berat dan sulit terurai sebagian bisa diubah seperti harga namun yang lainnya tidak mudah untuk diubah. Dalam hal ini titik yang menjadi fokus Alpha Glass adalah "visual image"atau kesan mewah yang diharapkan oleh pelanggan dalam penggunaan kaca untuk bangunan maupun interior.

Setelah mengetahui peta utilitas pembeli saat ini, langkah selanjutnya adalah mengembangkan wawasan dan mengenali calon konsumen di masa mendatang dengan menggunakan alat analisis "Tiga Tingkatan Non-konsumen" (three tiers of non-customers). Dalam Industri kaca lembaran saat ini, kategori tiga tingkat non-konsumen dapat dijelaskan seperti tabel 4. 


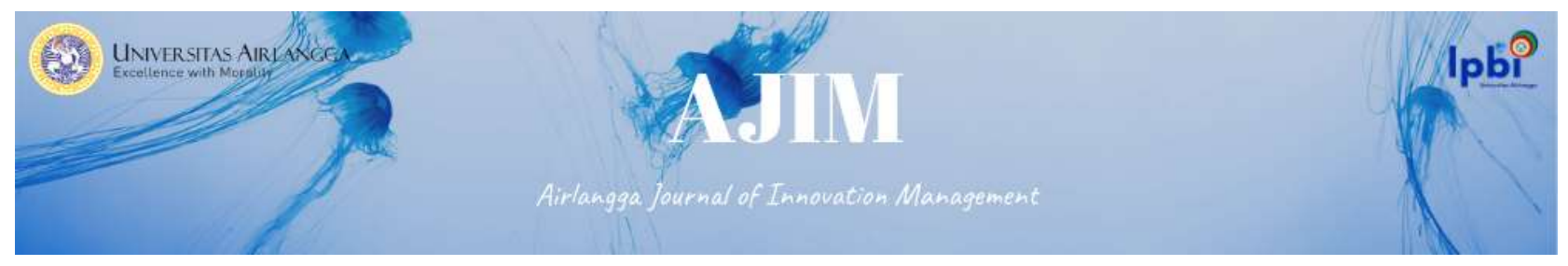

Tabel. 4

Tiga tingkat Non-konsumen pada Industri Kaca Lembaran

\begin{tabular}{|c|l|}
\hline $\begin{array}{c}\text { Non-konsumen tingkat } \\
\text { pertama }\end{array}$ & $\begin{array}{l}\text { konsumen yang membeli kaca karena tidak ada pilihan lain, mereka } \\
\text { membeli secara minimal sambil menunggu atau mencari alternatif yang } \\
\text { lebih baik. Contohnya adalah konsumen yang menggunakan kaca sebagai } \\
\text { bagian dari atap garasi mobil atau dinding ruangan agar cahaya masuk. }\end{array}$ \\
\hline $\begin{array}{c}\text { Non-konsumen tingkat } \\
\text { kedua }\end{array}$ & $\begin{array}{l}\text { konsumen yang menolak menggunakan kaca karena berbagai } \\
\text { pertimbangan antara lain kebutuhan mereka akan bahan kaca bisa } \\
\text { digantikan oleh bahan lain atau harga yang ditawarkan diluar jangkauan } \\
\text { mereka. Contohnya adalah konsumen yang menggunakan polikarbonat } \\
\text { sebagai etalase. }\end{array}$ \\
\hline kon-konsumen yang selama ini tidak pernah dianggap sebagai calon \\
konsumen potensial produk kaca lembaran karena mereka dianggap \\
berada diluar lingkungan industri kaca lembaran. Contohnya para arsitek \\
yang selama ini tidak pernah berpikir bahwa kaca dapat dipakai sebagai \\
dinding / partisi ruangan sekaligus dekorasi rumah yang kuat, aman dan \\
tahan lama.
\end{tabular}

(Sumber : Data diolah oleh penulis)

4. Langkah ke empat : Bagaimana perusahaan sampai di sana

Pada langkah ini merupakan penjabaran strategi perusahaan untuk mengeksekusi langkah pergeseran Samudra Biru. Pada langkah ini ada 2 hal yang harus dilakukan yaitu :

1. Merekonstruksi batas-batas pasar secara sistematis.

2. Mengembangkan peluang samudra biru alternatif.

Merekonstruksi batas pasar artinya menetapkan batas-batas pasar baru yang bertujuan untuk menciptakan nilai-biaya garis depan baru, alat analisis yang digunakan adalah "Kerangka Enam Jalur" (Kim \& Mauborgne, 2017). Kim dan Mauborgne mengembangkan kerangka enam jalur mereka "untuk melihat peluang di mana orang lain hanya melihat samudra merah kompetisi". Kerangka Enam Jalur yang dikembangkan dalam kasus Alpha Glass dapat dilihat pada gambar 5. Hal kedua yang harus dikerjakan pada langkah ini adalah mengembangkan peluang samudra biru alternatif dengan menggunakan alat analisis "Kerangka kerja empat tindakan" (The Four Actions Framework). Kerangka kerja empat tindakan disusun berdasarkan empat pertanyaan mengenai faktor-faktor apa saja yang dapat dihilangkan, dikurangi, dinaikkan dan diciptakan, yang dirangkum dalam matriks ERRC (EliminateReduce-Raise-Create).

Matriks ECCR dalam kasus Alpha Glass dapat dilihat pada Tabel 5. Matriks tersebut akan menjadi panduan bagi Alpha Glass mengenai bagaimana cara mengurangi struktur biaya, meningkatkan nilai pembeli dan menciptakan nilai baru atau kebutuhan baru untuk non-pelanggan. Tindakan yang akan dilakukan oleh Alpha Glass dalam menurunkan struktur biaya tercermin pada kolom "Eliminate" dan "Reduce". Faktor-faktor yang dapat dihilangkan antara lain mencegah produk gagal atau rejected, menghindari produksi yang melebihi order, mencegah trouble atau loss time, menghilangkan pemborosan dan mencegah timbulnya klaim dan komplain dari pelanggan. Faktor-faktor yang dapat dikurangi antara lain persediaan barang baik itu bahan baku maupun barang jadi, biaya-biaya yang tidak penting dan mengoptimalkan performa packing atau kemasan yang terlalu kuat. Untuk nilai-nilai yang perlu ditingkatkan antara nilai merek (brand value), pengiriman tepat waktu (on-time delivery) dan penanganan klaim \& komplain dengan cepat dan sederhana prosesnya. Untuk nilai-nilai yang diciptakan di masa depan diantaranya melalui penggunaan mobile Application dalam memesan kaca, menciptakan kaca yang lebih ringan, kaca yang dapat membersihkan sendiri serta kaca yang terintegrasi dengan 


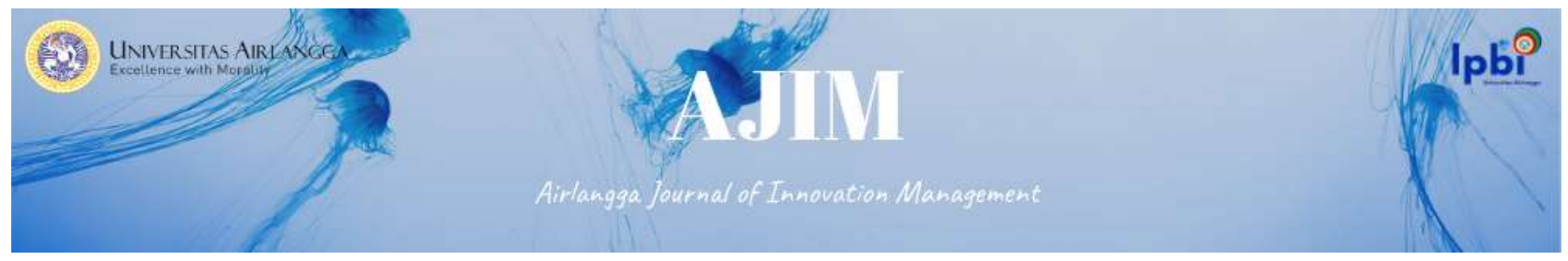

antenna $\mathrm{WiFi} 4 \mathrm{G} / 5 \mathrm{G}$.

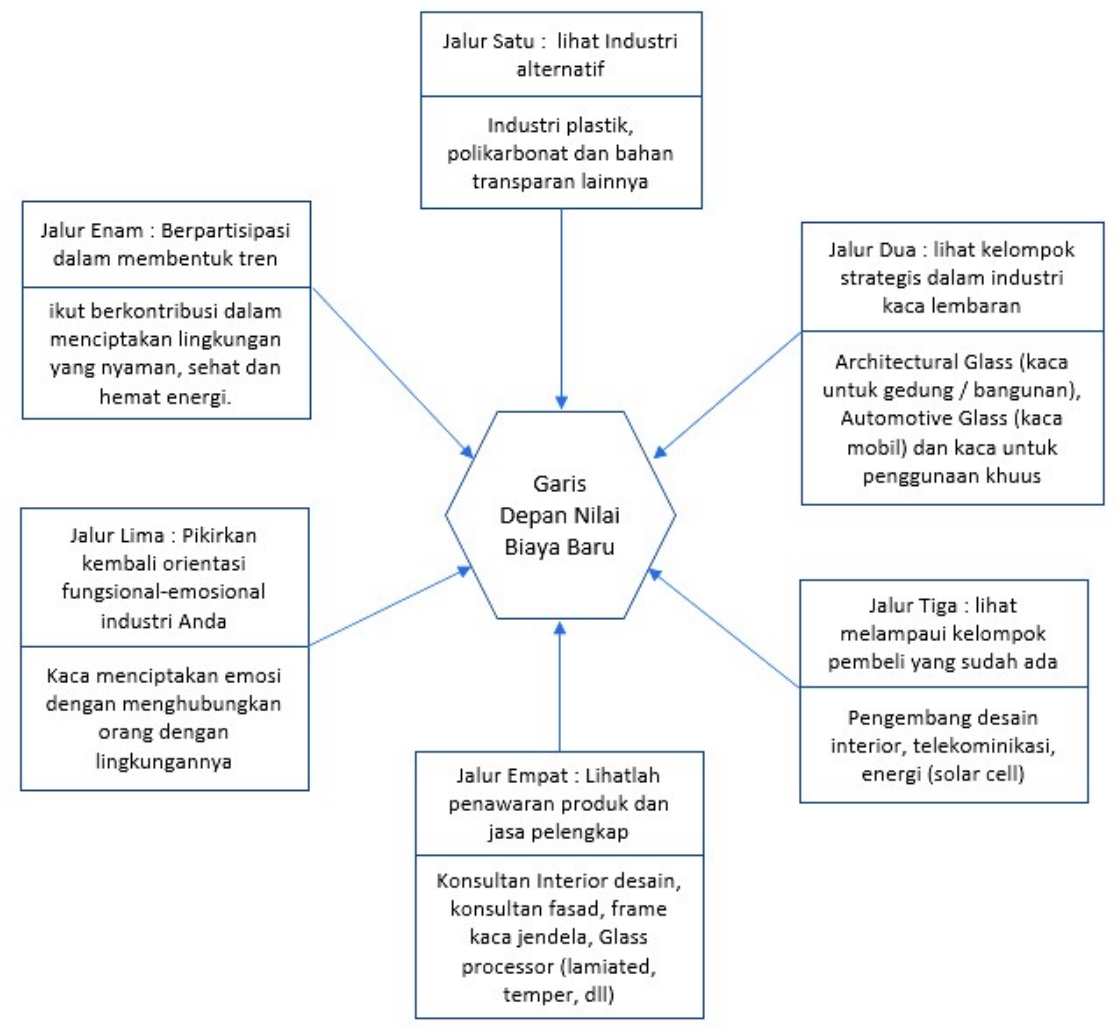

Gambar 5. Kerangka Enam Jalur yang digunakan Alpha Glass (Sumber : data diolah)

Tabel. 5

Matriks ECCR dari Alpha Glass

\begin{tabular}{|c|c|}
\hline $\begin{array}{l}\text { Eliminate } \\
\text { - Produk yang gagal / reject } \\
\text { - Produksi melebihi order } \\
\text { - trouble / loss-time } \\
\text { - waste time (pemborosan) } \\
\text { - jumlah "claim \& complaint" }\end{array}$ & $\begin{array}{l}\text { Raise } \\
\text { - meningkatkan "Brand Value" } \\
\text { - kecepatan pengiriman } \\
\text { (on time delivery) } \\
\text { - penanganan klaim \& komplain } \\
\text { (layanan purna jual) }\end{array}$ \\
\hline $\begin{array}{l}\text { Reduce } \\
\text { - Inventory (persediaan barang) } \\
\text { (Finish Good \& Raw Material) } \\
\text { - biaya secara keseluruhan } \\
\text { - performa / kekuatan kemasan } \\
\text { - kualitas yang tidak diperlukan }\end{array}$ & $\begin{array}{l}\text { Create } \\
\text { - smart order menggunakan } \\
\text { mobile App. } \\
\text { - kaca yang lebih ringan } \\
\text { - Self-cleaning glass } \\
\text { - integrated antennas } \\
\text { (antena 4G/5G menyatu dlm kaca) }\end{array}$ \\
\hline
\end{tabular}

(Sumber : data diolah) 


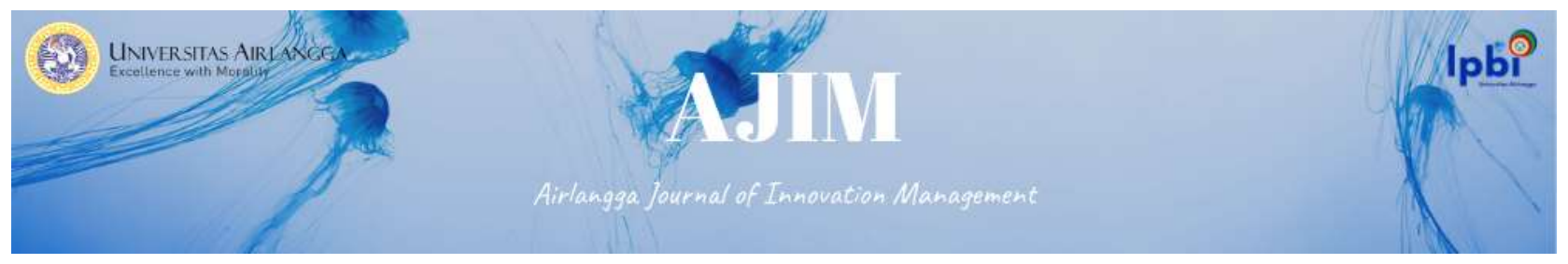

Rangkaian tindakan atau strategi yang dilakukan Alpha Glass diatas dituangkan dalam Kanvas Strategi masa depan Alpha Glass seperti di bawah ini.

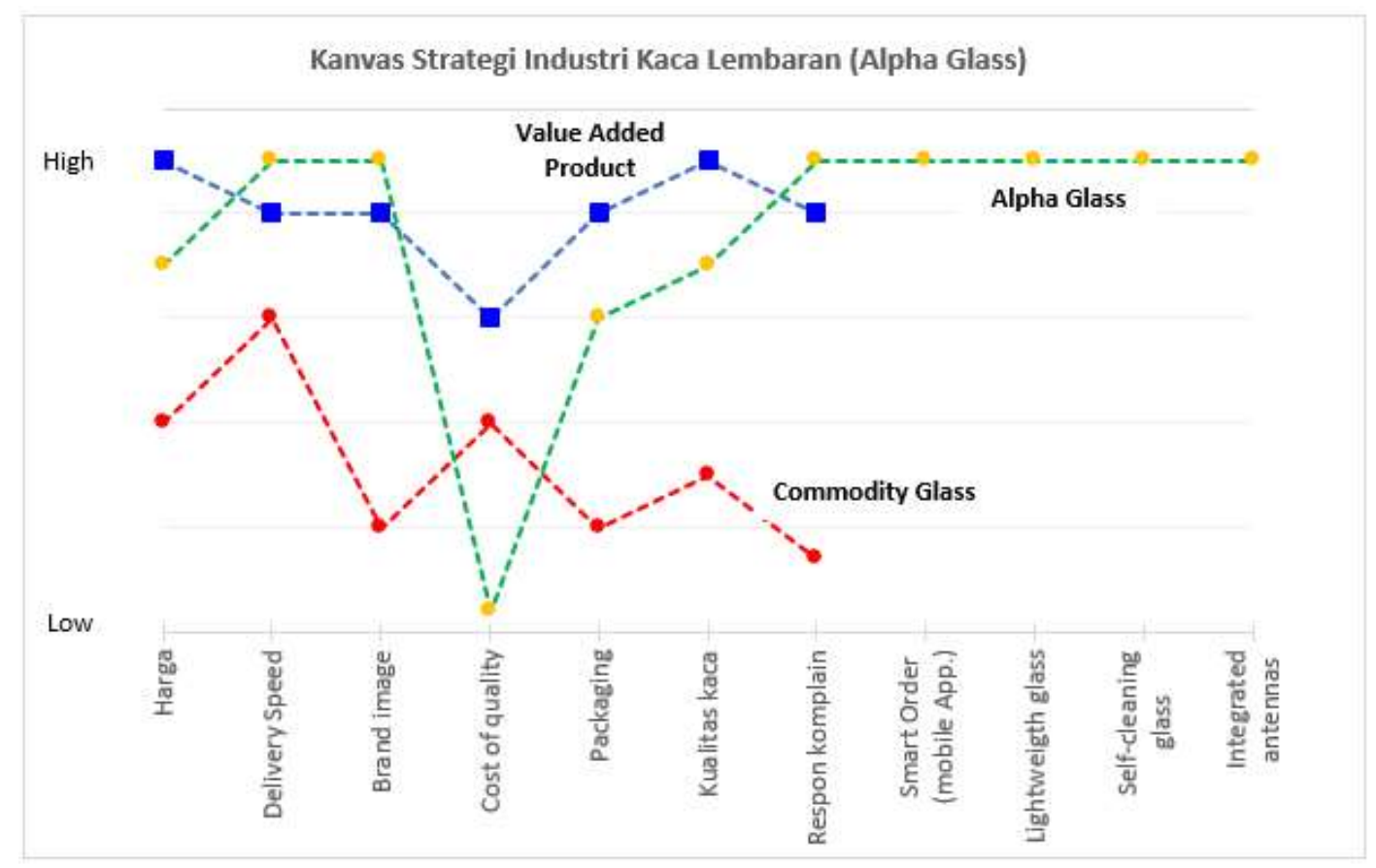

Gambar 6. Kanvas Strategi Masa Depan Alpha Glass (Sumber : data diolah)

5. Langkah ke lima : Eksekusi Strategi Samudra Biru

Setelah kerangka kerja strategi pergeseran Samudra Biru dirumuskan secara detil tahap demi tahap, langkah selanjutnya adalah mulai menyampaikan strategi baru ini kepada semua orang di dalam setiap tingkatan di organisasi Alpha Glass. Tujuan penyampaian ini agar semua elemen organisasi siap menghadapi perubahan yang akan dilakukan, memberikan umpan balik kepada perusahaan dan pada akhirnya semua mendukung perubahan ini. Pada langkah terakhir ini kunci keberhasilan tergantung pada bagaimana perubahan ini dikondisikan dan disosialisasikan kepada semua orang di Alpha Glass. Proses perubahan ini menurut Kim \& Mauborgne (2017), harus dilakukan dengan memperhatikan tiga elemen humanistik sebagai berikut.

1. Atomisasi: adalah proses penyelesaian tantangan menjadi langkah-langkah kecil yang dapat segera dilakukan.

2. Penemuan langsung adalah proses yang memungkinkan orang menemukan kebutuhan mereka sendiri untuk perubahan.

3. Proses yang adil adalah proses yang melibatkan semua karyawan dalam membangun kemauan bersama untuk menghadapi perubahan dan mengambil risiko di samudra biru dengan memupuk rasa saling menghormati dan saling percaya.

Langkah terakhir dalam proses pergeseran Samudra Biru ini merupakan proses perubahan yang melibatkan semua pemimpin dan karyawan serta pihak-pihak lain yang terlibat seperti Mitra Bisnis dan pihak ketiga lainnya. Mereka didorong untuk menemukan kebutuhan mereka sendiri akan perubahan, dan 


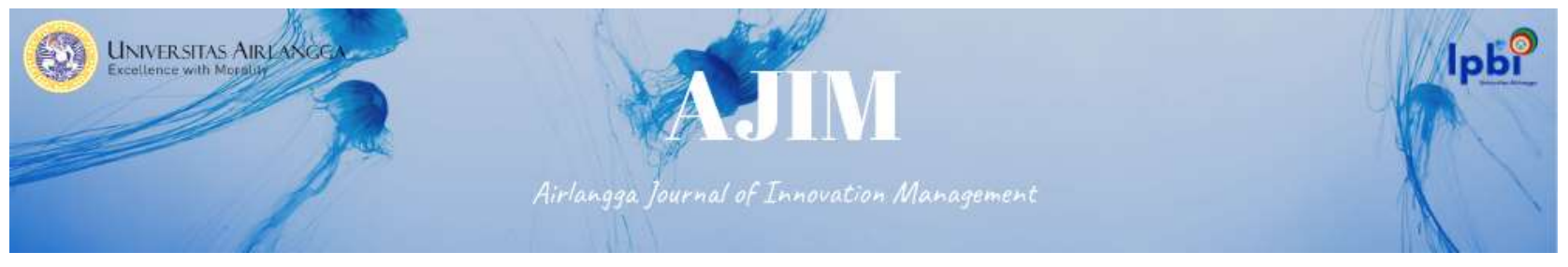

membangun kepercayaan, optimisme, dan kreativitas kolektif dalam proses pergeseran samudra biru ini.

\section{DISKUSI DAN PEMBAHASAN}

Tanda-tanda bahwa kondisi persaingan pasar kaca lembaran dalam negeri yang sedang dihadapi oleh Alpha Glass saat ini merupakan persaingan Samudra Merah, sesuai dengan kriteria persaingan Samudra Merah menurut Kim \& Mauborgne (2005:45), antara lain:

1) Penawaran lebih besar daripada permintaan di pasar domestik dengan masuknya kaca impor

Berikut ini data kapasitas produksi pabrik kaca lembaran dalam negeri terhadap permintaan pasar domestik dan kaca impor yang masuk ke pasar domestik serta ekspor kaca yang dilakukan oleh pemain lokal.

Tabel 6.

Neraca Pasar Kaca Lembaran Dalam Negeri volume (kilo-ton / tahun)

\begin{tabular}{lr}
\hline & volume (kilo-ton / tahun) \\
\hline Kapasitas Produksi Nasional & 1,300 \\
Permintaaan Domestik & 800 \\
Permintaan Ekspor & $300-400$ \\
$\quad$ Surplus Nasional & $100-200$ \\
Kaca impor yang masuk & 300 \\
$\quad$ Estimasi total surplus & $400-500$ \\
\hline
\end{tabular}

(Sumber : Asosiasi Kaca Lembaran dan Pengaman [AKLP], 2019)

Dari Tabel di atas, produksi kaca lembaran Nasional dibanding permintaan terdapat surplus sebesar 100-200 ribu ton per tahun bila utilisasi kapasitas produksi dimaksimalkan sampai 100\%, namun dalam kenyataannya utlisasi biasanya sekitar $90 \%$ sehingga antara total produksi dan permintaan hampir seimbang. Dengan masuknya kaca impor sekitar 300 ribu ton per tahun maka penawaran kan lebih besar dari permintaan atau terjadi surplus sekitar 400 - 500 ribu ton per tahun, ini menjadikan persaingan antara kaca lokal dan impor untuk memperebutkan pangsa pasar yg sama semakin berat dan mengarah pada persaingan hidup mati atau sum-zero game.

2) Meningkatnya kompetisi regional khususnya di kawasan Asia Tenggara dan kawasan Asia lainnya.

Peta persaingan di pasar kaca lembaran di kawasan Asia khususnya di China dan Asia Tenggara dapat digambarkan sebagai berikut :

2001-2011 : Pertumbuhan pabrik kaca di China meningkat 3 kali lipat

2012-2015 : Ekspor China ke kawasan ASEAN/Indonesia mulai meningkat

2016-2017 : Pabrik kaca China mulai membangun pabrik baru di Malaysia

Pertumbuhan jumlah pabrik kaca lembaran yang sangat pesat antara tahun 2001 sampai 2011 telah mendorong pabrik kaca lembaran di China untuk mengeskpor kelebihan produksinya ke kawasan Asia Tenggara termasuk Indonesia. Pasar kaca lembaran di kawasan Asia Tenggara merupakan salah satu kawasan yang masih terus bertumbuh ekonominya sehingga permintaan kaca lembaran juga terus naik.

Namun demikian ekspor kaca China ke negara-negara Asia Tenggara juga terkendala dengan berbagai aturan impor dan tarif di masing-masing negara tujuan sehingga mereka mulai berekspansi dengan membangun pabrik kaca lembaran baru di kawasan Asia Tenggara, khususnya di Malaysia dan kedepannya juga di Indonesia. Kondisi seperti ini menyebabkan tingkat persaingan di pasar kaca lembaran di kawasan Asia Tenggara meningkat dan menjadi semakin berat.

3) Terjadinya perang harga dan keuntungan yang semakin menipis 


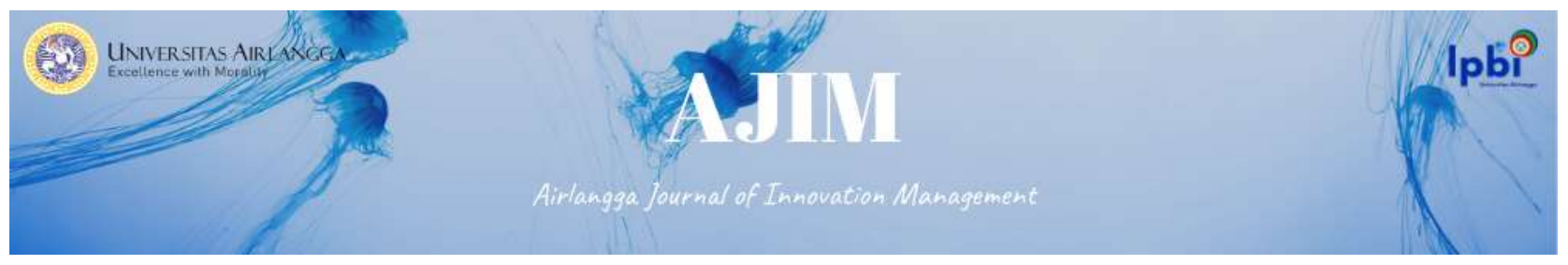

Kaca impor yang masuk ke pasar kaca lembaran domestik harganya lebih murah dibanding kaca produksi Industri kaca lembaran lokal dalam negeri. Strategi cost leadership yang dijalankan oleh pabrik kaca lembaran China ini memicu terjadinya perang harga di pasar kaca lembaran dalam negeri. Dalam menghadapi persaingan ini Alpha Glass mengalami kesulitan untuk menurunkan harga mengikuti pesaing karena struktur biaya produksi saat ini sudah terlanjur tinggi. Hal ini juga menyebabkan margin yang diterima Alpha Glass semakin menipis meskipun harga produknya masih lebih mahal dibanding pesaing. Berikut ini perbandingan harga jual dan margin Alpha Glass dibanding pesaing.

Tabel 7.

Perbandingan harga jual dan margin penjualan

\begin{tabular}{cccc}
\hline & Alpha Glass & Pesaing lokal & Kaca Impor \\
\hline Harga jual relatif & $6-7 \%$ lebih mahal & $3 \%$ lebih mahal & Pembanding \\
Margin (\%) & $4 \%$ & $11 \%$ & N/A \\
\hline
\end{tabular}

(Sumber : Data diolah oleh penulis)

Berdasarkan tiga indikator diatas dan diperkuat dengan hasil wawancara terhadap senior manajer Alpha Glass, dapat dilihat bahwa persaingan yang dihadapi Alpha Glass sangat berat dan menunjukkan persaingan Samudra Merah yang berdarah-darah sesuai dengan ciri-ciri kompetisi Samudra Merah yang dkemukakan oleh Kim \& Mauborgne (2015).

Meskipun demikian berdasarkan hasil wawancara dengan manajemen Alpha Glass, strategi yang digunakan dalam mengahadapi persaingan Samudra Merah saat ini bukan strategi Samudra Biru melainkan strategi generik Porter yaitu dengan melakukan diferensiasi dan penurunan biaya sekaligus atau differentiation with cost advantages. Perbandingan antara strategi Alpha Glass saat ini dengan Strategi Samudra Biru dapat dilihat pada Tabel 6.

Berdasarkan analisis data perkembangan teknologi dan manajemen di industri kaca lembaran dan hasil wawancara dengan manajemen Alpha Glass ada beberapa pertimbangan mengapa saat ini Alpha Glass masih menggunakan strategi generik Porter dibanding Strategi Samudra Biru, antara lain:

1. Industri kaca merupakan industri padat modal dengan teknologi yang sudah established, dimana dalam beberapa dekade terakhir ini tidak ada terobosan teknologi baru yang mendasar

2. Sampai saat ini (2019) belum ada kajian strategi Samudra Biru yang komprehensif pada industri kaca lembaran, sehingga belum ada satupun industri kaca lembaran di Indonesia dan kawasan Asia pada umumnya yang yang menjadikan strategi Samudra Biru sebagai strategi resmi perusahaan.

3. Strategi Perusahaan merupakan jantung pertumbuhan suatu perusahaan yang menentukan hidup mati suatu perusahaan, dan mempengaruhi seluruh aspek dalam organisasi sehingga dalam menentukan strategi yang akan diterapkan perusahaan harus sangat hati-hati dengan mempertimbangkan resiko dan kesiapan organisasi.

Meskipun ada beberapa kesulitan dan resiko dalam penerapan Strategi Samudra Biru pada Industri kaca lembaran seperti dijelaskan diatas namun berdasarkan data empiris di banyak organisasi dan perusahaan (Kim \& Mauborgne, 2015, 2017) membuktikan bahwa strategi yang paling efektif dalam menghadapi persaingan Samudra Merah adalah Strategi Samudra Biru. 


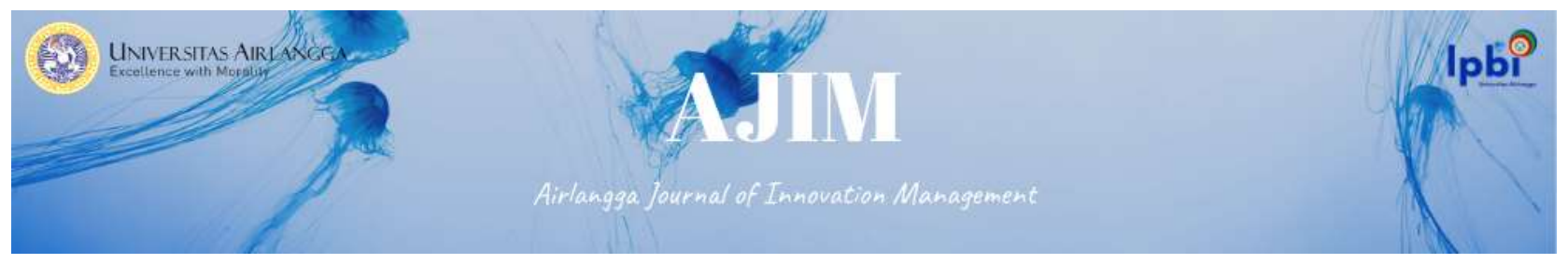

Tabel 8.

Perbandingan Strategi Alpha Glass saat ini dan Strategi Samudra Biru

\begin{tabular}{|l|l|l|}
\hline \multicolumn{1}{|c|}{ Elemen Strategi } & \multicolumn{1}{|c|}{ Strategi Alpha Glass } & \multicolumn{1}{c|}{ Strategi Samudra Biru } \\
\hline \hline Sasaran & $\begin{array}{l}\text { Memenangkan persaingan di } \\
\text { pasar yang sama }\end{array}$ & Menciptakan pasar baru \\
\hline Fokus / Prioitas & $\begin{array}{l}\text { Value Added Product } \\
\text { (differensiasi) dan Cost down } \\
\text { dilakukan terpisah }\end{array}$ & $\begin{array}{l}\text { Value Added Product } \\
\text { (differensiasi) dan Cost down } \\
\text { dilakukan secara simultan }\end{array}$ \\
\hline Keunggulan kompetitif & $\begin{array}{l}\text { Meciptakan produk yang } \\
\text { unggul dan menarik bagi } \\
\text { pelanggan }\end{array}$ & $\begin{array}{l}\text { Mengeksplorasi nilai-nilai } \\
\text { baru non-konsumen }\end{array}$ \\
\hline Manajemen Portofolio & $\begin{array}{l}\text { Menjaga kestabilan } \\
\text { pendapatan perusahaan } \\
\text { melalui manajemen } \\
\text { portofolio }\end{array}$ & $\begin{array}{l}\text { Menjaga keseimbangan } \\
\text { portofolio saat ini (stabilitas } \\
\text { pendapatan saat ini) dan } \\
\text { portofolio masa depan }\end{array}$ \\
\hline
\end{tabular}

(Sumber : Data diolah oleh penulis)

Berdasarkan rancangan kerangka kerja Pergeseran Samudra Biru yang telah disusun dalam kasus persaingan yang dihadapi oleh Alpha Glass, dapat disimpulkan bahwa Lima langkah sistematis Pergeseran Samudra Biru dapat membantu Alpha Glass dalam menerapkan Strategi Samudra Biru di pasar kaca lembaran dalam negeri.

Langkah untuk menciptakan pasar baru merupakan tujuan utama dari strategi Samudra Biru, langkah ini akan menentukan apakah Alpha Glass dapat menciptakan pasar yang sama sekali baru dan tanpa pesaing atau sebaliknya tidak dapat. Bila perusahaan dapat menciptakan pasar baru mereka akan sukses masuk ke Samudra Biru, sebaliknya bila tidak berhasil mereka akan terjebak pada Samudra Merah. Pada kasus Alpha Glass ini ada peluang untuk menciptakan pasar baru kaca lembaran dengan mengembangkan kaca yang sama sekali berbeda dengan yang sekarang yaitu kaca yang tidak mudah pecah, lebih ringan namun tetap kuat dan aman.

Langkah penting selanjutnya adalah langkah untuk merealisasikan Samudra Biru. Langkah ini berisi cara bagaimana melaksanakan Strategi Samudra Biru dengan menggunakan alat analisis utama Kerangka Kerja Empat Tindakan yang dituangkan dalam matriks ECCR untuk menyusun kanvas strategi baru yang menggambarkan strategi yang akan diambil Alpha Glass kedepannya. Kanvas strategi ini juga menggambarkan posisi penawaran Alpha Glass terhadap pesaing dan nilai-nilai baru atau inovasi nilai yang ditawarkan kepada konsumen yang tidak dimiliki oleh pesaing lainya.

\section{KESIMPULAN}

Persaingan pada Industri kaca lembaran di Indonesia saat ini sangat ketat dan sudah mengarah pada kompetisi Samudra Merah yang berdarah-darah. Tanda-tanda persaingan yang dihadapi Alpha Glass hampir semuanya sesuai dengan kriteria Samudra merah yang disampaikan oleh Kim \& Mauborgne ( Kim \& Mauborgne, 2015). 


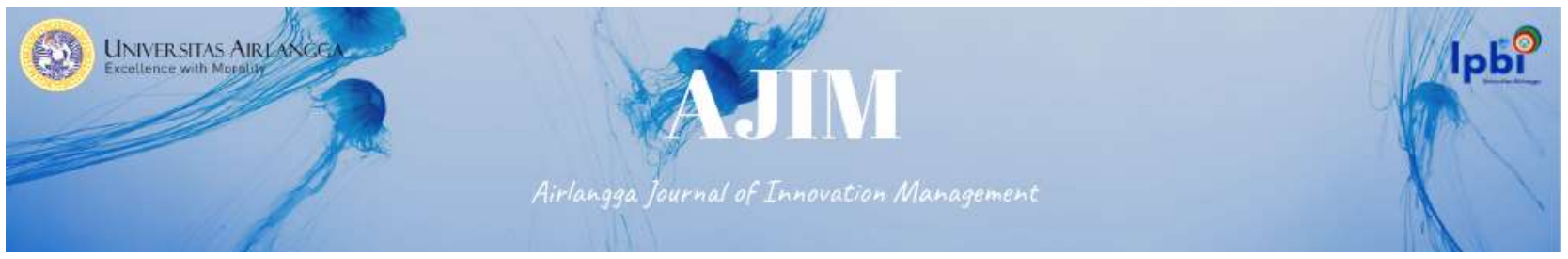

Berdasarkan Kerangka Kerja Pergeseran Samudra Biru yang telah disusun dalam kasus persaingan yang dihadapi Alpha Glass dapat disimpulkan bahwa strategi Samudra Biru ini bisa diimplementasikan dengan baik oleh Alpha Glass, hal-hal yang mendukung adalah persamaan antara strategi Alpha Glass saat ini dan Strategi Samudra Biru diataranya adalah :

1. Komposisi portofolio Alpha Glass di masa depan akan berfokus pada Value Added Product (Diferensiasi)

2. Mengusahakan penurunan biaya pada semua faktor diseluruh sisi organisasi (Cost Reduction)

3. Beberapa faktor yang direkomendasikan pada Matrik ERRC (Eliminate-Reduce-RaiseCreate) sama dengan langkah strategi yang sudah dilakukan oleh Alpha Glass

4. Sistem Kaizen (perbaikan terus menerus) yang menjadi budaya Alpha Glass dapat menjadi sumber ide dan inovasi Samudra Biru.

5. Peran serta seluruh karyawan dan semua elemen organisasi dalam melaksanakan keputusan manajemen Alpha Glass sangat kuat, dibuktikan dengan sistim perbaikan berkesinambungan saat ini sudah dilakukan oleh seluruh karyawan dari level paling bawah sampai manejerial.

Namun demikian, terdapat perbedaan mendasar antara Strategi Alpha Glass saat ini dengan Strategi Samudra Biru. Perbedaan paling mendasar adalah, dalam Strategi Samudra Biru inovasi dilakukan untuk menciptakan pasar yang baru dan ditujukan untuk non-konsumen atau calon konsumen di masa depan, hal ini berbeda dengan strategi Alpha Glass yang hanya berfokus pada pasar yang sudah ada saat ini. Perbedaan lainnya adalah dalam mengelola keunggulan produk (differentiation) dan biaya rendah (cost leadership), dalam strategi Samudra Biru keduanya saling melengkapi bukan berlawanan atau berjalan sendiri-sendiri.

Berdasarkan hasil penelitian ini dapat disimpulkan bahwa Strategi Samudra Biru lebih tepat digunakan dalam menghadapi persaingan di pasar kaca lembaran saat ini dibandingkan dengan strategi generik Porter yang saat ini digunakan oleh PT Alpha Glass.

Implikasi manajerial dalam penelitian ini adalah untuk memberikan wawasan mengenai implementasi Strategi Samudra Biru pada industri kaca secara lengkap dan komprehensif bagi manajemen Alpha Glass dalam menentukan arah strategi kedepannya. Wawasan ini nantinya juga perlu disesuaikan dengan kondisi ekonomi global, perkembangan teknologi dan aturan baru, baik di skala lokal mapun global.

Dalam penerapan langkah-langkah Pergeseran Samudra Biru ini perlu diwaspadai jebakanjebakan Samudra Merah yang menghambat proses pergeseran menuju samudra Biru. Jebakan Samudra Merah ini bila tidak diantisipasi dengan sungguh-sungguh akan menjadi batu sandungan yang menyebakan perusahaan gagal bertranformasi ke Samudra Biru sehingga kerugian perusahaan semakin besar.

Dalam penelitian ini rancangan strategi pergeseran Samudra Biru yang disusun belum teruji secara nyata dilapangan, untuk penelitian selanjutnya disarankan agar tidak hanya membahas evaluasi implementasi pergeseran Samudra Biru di Alpha Glass tetapi juga faktor-faktor luar turut mempengaruhi keberhasilan atau kegagalan panerapan strategi Samudra Biru seperti kondisi ekonomi global, dukungan dari pemerintah dan perubahan kebijakan atau model bisnis yang terjadi pada perusahaan tersebut. Dukungan dari pemerintah sangat diperlukan untuk melindungi industri kaca lembaran Nasional antara lain regulasi impor kaca lembaran yang masuk ke Indonesia dan kebijakan penurunan harga gas Industri dimana saat ini harga gas dalam negeri masih lebih tinggi dibanding negara tetangga.

\section{UCAPAN TERIMA KASIH}

Penelitian ini dapat dilaksanakan berkat bantuan, bimbingan dan dukungan dari berbagai pihak, pada kesempatan ini penulis menyampaikan rasa terimakasih sebesar-besarnya kepada Prof. Dr. Bambang Tjahjadi, MBA., Ak., CMA., CA., yang telah mendukung, membimbing dan memberikan arahan dalam penelitian dan penyusunan jurnal ini. Terimakasih juga penulis sampaikan segenap jajaran Direksi dan Manajemen PT Alpha Glass yang telah meluangkan waktu, tenaga dan pikiran untuk terlibat dalam penelitian ini. 


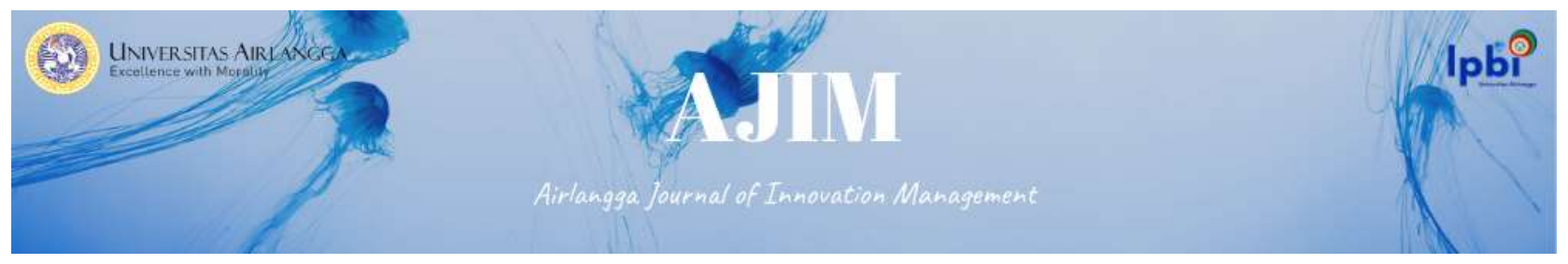

\section{DAFTAR PUSTAKA}

Adair, J. (2009), Effective Innovation: How to Stay Ahead of the Competition, New Revised Edition. Pan Books, Pan Macmillan Ltd.

AGC Group. (2016). On The Long term Group Strategy : Vision 2025, The AGC Group Magazine No. 56, 1st Quarter 2016.

Asahimas Flat Glass, Tbk. (n.d.), Sejarah Perusahaan, retrieved from http://www.amfg.co.id/id/ perusahaan/seputar-kami/tentang-kami.html

Asahimas Flat Glass, Tbk. (2015-2018), Annual Report of 2015 - 2018, retrieved from http://www.amfg.co.id/en/investor/investor-information/annual-report

Asosiasi Kaca Lembaran dan Pengaman [AKLP] (2019), Retrieved from https://www.wartaekonomi.co.id/read256411/kemenperin-dorong-industri-kaca-tambahkapasitas-terpasang.html

Christensen, C. M. \& Raynor, M. (2003). The innovator's solution : creating and sustaining successful growth. Boston, Mass.: Harvard Business School Press

Christensen, C. M., Altman E.J., McDonald, R., Palmer, J. (2016). Disruptive Innovation: Intellectual History and Future, Boston, Mass.: Harvard Business School Press

Dinnata, R.Y.W., (2017, October $17^{\text {th }}$ ), Asosiasi Kaca Berniat Bangkitkan Pabrik Tossa yang Setop Produksi, Bisnis.com, retrieved from https://ekonomi.bisnis.com/read/20171017

Fleisher, C.S. \& Bensoussan, B.E. (2015). Business and Competitive Analysis : Effective Application of New and Classic Methods. Pearson Education, Inc., Upper Saddle River, New Jersey

Grant, R. M. (2016), Contemporary strategy analysis : text and cases, John Wiley and Sons; 9th Revised edition

Govindarajan, V., Matin, J., Shashikumar, VK. (2012), Get to Know Your Non-Customer, Harvard Business Review, August 2012.

Gaynor, G.H. (2002), Innovation by Design: What It Takes to Keep Your Company on the Cutting Edge, New York : AMACOM

Hana, D. O. (2019, October 31st), Industri Kaca Lembaran Tuntut Harga Gas Kompetitif, Bisnis.com, retrived from https://ekonomi.bisnis.com/read/20191031/257/1165476/industri-kaca-lembarantuntut-harga-gas-kompetitif

Hansen, M.T. \& Birkinshaw, J. (2007), The Innovation Value Chain, Boston, MA: Harvard Business Review.

Hendrianto, D., Kasim, A. (2017), Perumusan Blue Ocean Strategy PT Lippo General Insurance Tbk menjadi Leader di Industri Asuransi Indonesia, Jurnal Riset Perbankan Manajemen dan Akuntansi Vol.1 No.2, 2017

Kelley, T. \& Litmann J. (2001), The Art of Innovation : Lessons in Creativity from IDEO, America's Leading Design Firm, Broadway Business, 2001.

Kim, W.C. \& Mauborgne, R. (2005), Blue ocean strategy: how to create uncontested market space and make the competition irrelevant, Harvard Business School Publishing Corporation

Kim, W.C. \& Mauborgne, R. (2017), Blue Ocean Shift (Indonesian Edition : Pergeseran Samudra Biru), Gramedia Pustaka Utama.

Kibing Group. (2016). Retrieved from http://www.kibing-glass.com/en/investor.php

Kotler, P. and Kevin L.K., (2016): Marketing Management, 15th Edition New Jersey: Pearson Pretice Hall, Inc.

Leavy, B. (2018), "Value innovation and how to successfully incubate "blue ocean" initiatives", Strategy \& Leadership, Vol. 46 Issue: 3, pp.10-20

McGrath, R.G. (2012), The End of Competitive Advantage: How to Keep Your Strategy Moving as Fast 


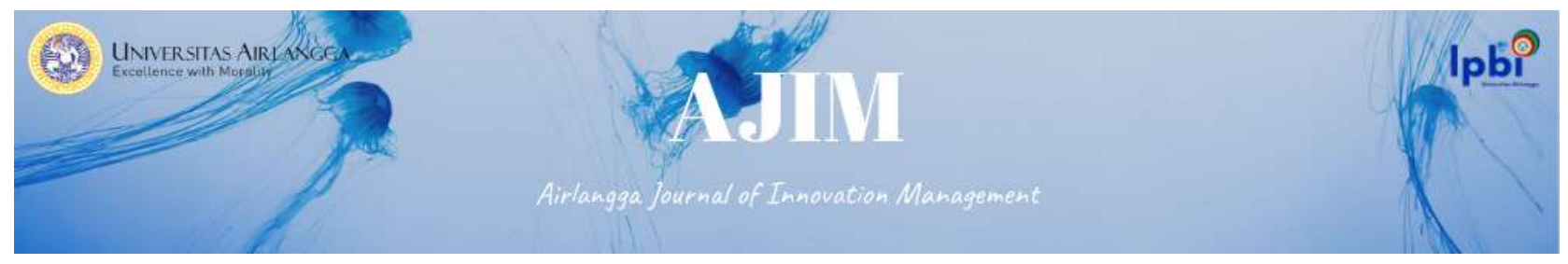

as Your Business, Harvard Bussiness Review Press

Morris G. (2016, September 20th), Kibing set to increase investment in Malaysia, The Glass International, retrivieved from https://www.glass-international.com/news/kibing-set-to-increaseinvestment-in-malaysia

Mulia Industrindo, Tbk. (2015-2018), Annual Report of 2015 - 2018, retrieved from https://muliaindustrindo.com/id/info-investor/index

NSG Group. (2010). Pilkington and the Flat Glass Industry 2010, Nippon Sheet Glass Co., Ltd.

Porter, M.E. 1985. Competitive Advantage : Creating and Sustaining Superior Performance : with a new introduction, The Free Press. New York, USA

Pisano, G.P. (2015), You Need an Innovation Strategy, Harvard Business Review, June 2015 Issue.

Prahalad, CK; Ramaswamy, V. (2004). The Future of Competition. Harvard Business School Press.

Rini, A.S. \& Ihsan, M. (2018, Agustus $\left.29^{\text {th }}\right)$, DAYA SAING MANUFAKTUR NASIONAL : Ancaman Raksasa Kaca Negeri Jiran, Bisnis.com, retrieved from https://surabaya.bisnis.com/read/20180829/447/832622/daya-saing-manufaktur-nasionalancaman-raksasa-kaca-negeri-jiran

Rumelt, R.P. (2011), Good Strategy Bad Strategy: The Difference and Why It Matters, London: Profile Books, 2011

Rajasekaran, R. (2016), Blue Oceans in Indian Sesame Oil Industry: A Case Analysis, Indian University Press

Satell, G. (2017), Mapping Innovation: A Playbook for Navigating a Disruptive Age, New York, NY: McGraw-Hill.

Sempels, C. \& Hoffmann, J. (2013), Sustainable Innovation Strategy : Creating Value in a World of Finite Resources, Palgrave Macmillan.

Saputri, M.E., Mulyaningsih, H.D. (2016), Blue Ocean strategy for creating value innovation: A study over Kedai Digital in Yogyakarta, Indonesia, Journal of Administrative and Business Studies 2016, 1(1): 14-20

Statista (2019). Retrieved from https://www.statista.com/statistics/697265/flat-glass-market-volumeworldwide-by-application

Utaminingsih, I.A. (2011), Rancangan Strategi Samudra Biru PT. SILKARGO Indonesia, Journal of Management and Business Review, Vol.8, No.1, January 2011: 15-33

United Nations, Commodity in Trade [UN-Comtrade] (2019). Retieved from https://comtrade.un.org/Data

Xinyi Glass Holding Limited. (2016-2017), Annual Report of 2016 - 2017, retrieved from $\mathrm{http} / / / \mathrm{www} \cdot$ xinyiglass.com/en/index.php

Yin, R. K. (2018). Case study research and applications : design and methods, 6th edition. Los Angeles, SAGE Publication Inc. 


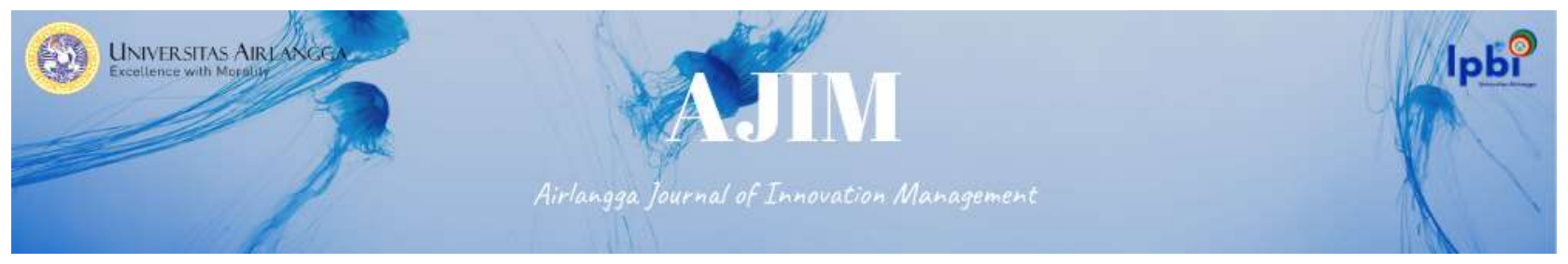

\section{Lampiran. Pertanyaan wawancara}

Wawancara semi-terstruktur.Pertanyaan-pertanyaan umum disiapkan di awal, namun dapat disesuaikan berdasarkan tanggapan.

\section{Strategi dan Peta Persaingan Industri kaca lembaran di dalam negeri}

- Bagaimana kondisi persaingan industri kaca lembaran di dalam negeri saat ini ?

- Menurut anda apa strategi yang paling tepat untuk menghadapi kondisi diatas ?

- Apakah strategi perusahaan saat ini sudah sesuai untuk menghadapi kondisi persaingan saat ini dan di masa depan?

- Bagaimana peran perusahaan dalam menumbuhkan budaya inovasi di semua tingkatan organisasi saat ini ?

- Jenis inovasi apa yang paling tepat untuk menjawab tantangan perusahaan saat ini ? (inovasi teknologi, inovasi nilai, inovasi sistem atau lainnya), tolong dijelaskan alasannya.

\section{Langkah Pergeseran Strategi Samudra Biru}

- Bagaimana posisi perusahaan dalam peta persaingan industri kaca saat ini ?

- Bagaimana komposisi portofolio perusahaan saat ini dan bagaimana komposisi portofolio (produk generik dan produk dengan nilai tambah / inovasi) yang paling ideal untuk menjawab tantangan di masa depan

- Faktor-faktor apa yang menjadi kunci persaingan dalam industri kaca lembaran saat ini ?

- Bagaimana posisi penawaran perusahaan pada faktor-faktor tersebut?

Pertanyaan penutup:

Apakah Anda ingin menguraikan masalah yang terkait dengan strategi perusahaan di masa depan, yang menurut anda penting tetapi tidak termasuk dalam pertanyaan di atas? 